\title{
LA INCORPORACIÓN DE LA NOBLEZA AL ALTO CLERO EN EL REINO DE CASTILLA DURANTE LA BAJA EDAD MEDIA ${ }^{1}$
}

\author{
JORGE DÍAZ IBÁÑEZ ${ }^{2}$
}

\begin{abstract}
Resumen: En este artículo se estudia cómo muchos clérigos procedentes de la nobleza castellana alcanzaron entre los siglos XIII y XIV la más alta jerarquía eclesiástica del reino, sobre todo dentro del episcopado y en los cabildos catedralicios, donde habrá tanto clérigos procedentes de la baja y mediana nobleza como de grandes linajes tales como los Manrique, Carrillo, Fonseca, Mendoza, Albornoz, Gómez de Toledo, Guzmán o Luna.
\end{abstract}

Palabras clave: Clero secular; Nobleza; Reino de Castilla; Siglos XIII-XV.

Abstract: In this article we study how a lot of clergymen members of the castilian nobility joined, between 13th and 15th centuries, to the high ecclesiastical hierarchy of the kingdom, mainly to the Episcopacy and chapters of the cathedrals, where there will be clergymen proceeding from low nobility and also from high noble families like Manrique, Carrillo, Fonseca, Mendoza, Albornoz, Gómez de Toledo, Guzmán or Luna.

Keywords: Clergy; Nobility; Kingdom of Castile; 13th-15th centuries.

\section{SUMARIO}

1. El Episcopado. 2. Los cabildos catedralicios. 3. Otros eclesiásticos. Conclusiones.

El proceso de integración de un gran número de miembros de la nobleza castellana bajomedieval, en sus diferentes niveles, dentro del estamento eclesiástico es una cuestión cuyo estudio resulta de gran importancia para un mejor conocimiento de la sociedad castellana durante estos siglos,

${ }^{1}$ El presente trabajo se ha realizado en el marco del Proyecto de Investigación del Ministerio de Ciencia y Tecnología I $+\mathrm{D}+\mathrm{I} \mathrm{n}^{\circ}$ BHA-2002-03388, titulado La Monarquía como conflicto en la Corona de Castilla, 1230-1504, y radicado en el Departamento de Historia Medieval de la Universidad Complutense de Madrid.

${ }^{2}$ Departamento de Historia Medieval, Facultad de Geografía e Historia, Universidad Complutense de Madrid.

Fecha de recepción del artículo: junio 2005; fecha de aceptación y versión final: julio 2005.

«Anuario de Estudios Medievales», 35/2 (2005), pp. 557-603.- ISSN 0066-5061. 
pero a pesar de ello, salvo pequeñas aproximaciones ${ }^{3}$, todavía no ha recibido la suficiente atención por parte de nuestra moderna historiografía ${ }^{4}$.

Es sobre todo dentro del clero secular, y fundamentalmente en el ámbito urbano, donde antes y mejor se aprecia el paulatino pero imparable proceso de incorporación de personajes de la nobleza a medios y altos cargos en el estamento eclesiástico, pasando a formar parte, sobre todo, del Episcopado y de los cabildos catedralicios, proceso que ya se comienza a observar durante el siglo XIII, si bien sus raíces podrían remontarse incluso a tiempo atrás, y cuyo máximo desarrollo tendrá lugar en los siglos XIV y $\mathrm{XV}$, época de expansión tanto de las oligarquías urbanas y pequeños y medianos linajes nobiliarios como de los grandes linajes de la nobleza nueva. En este sentido, se ha señalado cómo el celibato eclesiástico, independientemente de las voluntades individuales, respondía muchas veces a los intereses de los propios linajes, que también necesitaban una proyección en el seno de la institución eclesiástica, encontrando aquí la dimensión propagandística de la espiritualidad una de sus vertientes más importantes 5 .

Este proceso, además, estará íntimamente relacionado y evolucionará en paralelo con la formación de amplias redes clientelares de eclesiásticos en torno al poder real, procedentes sobre todo de los ámbitos episcopal y catedralicio, que poco a poco se irán incorporando a importantes funciones gubernativas y administrativas del reino ${ }^{6}$.

A continuación estudiaremos, no exhaustivamente, sino tan sólo en sus rasgos generales mediante el análisis de ejemplos significativos, cómo

\footnotetext{
${ }^{3}$ Algunos ejemplos sobre ello en J. DíAz IBÁÑEZ, Las relaciones Iglesia-Nobleza en el obispado de Cuenca durante la baja Edad Media, "En la España Medieval", 20 (1997), pp. 281320; Marta GonzÁlez VÁzouEZ; J. PÉREZ RodríGuez, Aproximación al estudio de las relaciones familiares y de poder en una institución eclesiástica: el cabildo compostelano en los siglos XII y XIII, "Hispania", 53/185 (1993), pp. 1091-1098; Isabel GARCÍA DíAZ; Miguel RODRÍGUEZ LlOPIS, Iglesia y sociedad feudal: el cabildo de la catedral de Murcia en la baja Edad Media, Murcia, 1994. Para época moderna resulta de interés, entre otros trabajos, el conjunto de estudios recogidos en Sociedad y élites eclesiásticas en la España moderna (coord. F.J. ARANDA PÉREZ), Cuenca, 2000.

${ }^{4}$ Así, en algunas síntesis generales publicadas en los últimos años sobre la nobleza de los reinos hispánicos medievales apenas se toca el tema de las relaciones con la Iglesia. Vid. MarieClaude GERBET, Las noblezas españolas en la Edad Media. Siglos XI-XV, Madrid, 1997.

${ }^{5} \mathrm{M}^{\mathrm{a}}$ Concepción Quintanilla Raso, La Nobleza, en “Orígenes de la Monarquía Hispánica: Propaganda y legitimación” (Dir. José Manuel NIETO SORIA), Madrid, 1999, p. 91.

${ }^{6}$ Sobre las clientelas eclesiásticas en la Castilla bajomedieval puede verse el trabajo de J.M NIETO SORIA; J. DíAZ IBÁÑEZ, Élites y clientelas eclesiásticas (siglos XIII al XV): propuestas metodológicas desde el caso castellano, en "Elites e redes clientelares na Idade Média: Problemas metodológicos" (edit. F. THEMUDO BARATA), Lisboa, 2001, pp. 109-139.
}

«Anuario de Estudios Medievales», 35/2 (2005), pp. 557-603.- ISSN 0066-5061. 
muchos miembros de la nobleza, en sus diferentes niveles, se fueron incorporando al estamento eclesiástico, y la evolución y tendencias de este proceso durante los siglos bajomedievales, diferenciando en este estudio tres ámbitos fundamentales de análisis: el Episcopado, los cabildos catedralicios $\mathrm{y}$, finalmente, otros niveles del estamento clerical.

\section{EL EPISCOPADO}

El acceso de miembros de la nobleza al Episcopado, que ya se dio a veces en los reinos cristianos durante la época plenomedieval, se seguirá produciendo durante la baja Edad Media, y de forma particularmente acusada en el siglo XV, pudiendo ello constatarse en mayor o menor medida según la sede de que se trate.

El procedimiento utilizado por determinadas familias de la nobleza local cuando aspiraban a que alguno de sus miembros alcanzara la titularidad de la mitra podía consistir, primeramente, en la incorporación de algunos segundones del linaje al cabildo catedralicio, como paso previo, aunque no en todos los casos necesario, para su ascenso al Episcopado, gracias al posible control a su favor - a veces incluso monopolio- que, una vez dentro de la institución capitular, podían llegar a ejercer sobre las elecciones episcopales.

En este sentido, algunos estudios han demostrado que, por ejemplo, para el caso de todas las diócesis pertenecientes a la provincia eclesiástica de Toledo durante el periodo comprendido entre 1252 y 1312, así como en las sedes de Burgos, Calahorra, Ávila y Cartagena durante la misma época, aproximadamente un cincuenta por ciento de las elecciones sobre las que se dispone de datos fiables fueron efectuadas por el correspondiente cabildo catedralicio, aunque a veces con algún tipo de intromisión real o pontificia en las mismas, y además consta que en casi un cuarenta por ciento del total de elecciones cuyo desarrollo está bien documentado hubo una clara injerencia del monarca en las mismas ${ }^{7}$. De este modo, por tanto, algunos linajes que habían destacado por sus servicios a la Realeza en empresas políticas y militares, también buscaron la mediación y apoyo regios a favor de alguno de sus miembros de cara a la obtención de una determinada sede episcopal.

${ }^{7}$ José Manuel NiETo SoRIA, Iglesia y poder real en Castilla. El Episcopado, 1250-1350, Madrid, 1988, p. 201.

«Anuario de Estudios Medievales», 35/2 (2005), pp. 557-603.- ISSN 0066-5061. 
Centrándonos en el siglo XIII, que es cuando se sitúan más claramente los inicios de la incorporación nobiliaria al alto clero, señalaremos a continuación algunos ejemplos de sedes en las que ya durante esta época ello puede constatarse. Primeramente, comenzando por las diócesis gallegas, cabría destacar la archidiócesis compostelana, donde comenzará a ser algo habitual que los obispos procedan de la nobleza regional galaico-asturiana: tal fue el caso del arzobispo de Santiago Juan Arias (1238-1266), uno de los prelados más representativos de la centuria, que trató de reforzar la posición del arzobispo como cabeza de la Galicia señorial, y que además tenía muchas clientelas en la corporación capitular que sin duda contribuirían a fortalecer las redes familiares del linaje ${ }^{8}$. En cambio en otras diócesis menos relevantes del ámbito gallego, como por ejemplo Mondoñedo, donde durante el XIII hubo sobre todo obispos originarios de Galicia, todavía no nos consta para esta época una destacada presencia de prelados procedentes de familias nobiliarias, lo que en cambio sí ocurrirá durante las dos centurias siguientes?. Algo parecido sucederá en Astorga, donde antes del siglo XV la representación nobiliaria entre el Episcopado, aunque existió en ciertas ocasiones, no tendrá demasiado relieve ${ }^{10}$, así como en otras diócesis del norte peninsular como Osma o Calahorra. Pero en Palencia, sin embargo, nos encontramos a fines de siglo con el obispo Álvaro Gómez Carrillo (1297-1305), un conspicuo representante de la nobleza castellana y asiduo colaborador de la Monarquía ${ }^{11}$.

En el obispado de Ávila, donde durante el siglo XII los obispos habían procedido sobre todo de la oligarquía local formada por el grupo religiosomilitar de los guerreros de fronter ${ }^{12}$, hay que destacar la presencia ya desde el siglo XIII de un importante linaje de la ciudad que extenderá su poderosa influencia al ámbito eclesiástico. Se trata de los Dávila, señores de Navamorcuende-Cardiel. A este linaje perteneció el obispo abulense Domingo Blasco, dentudo, titular de la mitra entre 1213 y 1239, hijo del adalid Sancho

\footnotetext{
${ }^{8}$ José GARCía ORo (coord.), Iglesias de Santiago de Compostela y Tuy-Vigo, en "Historia de las diócesis españolas", Madrid, 2002, XIV, pp. 68-70.

${ }^{9}$ Enrique CAL PARDo, Episcopologio mindoniense. Baja Edad Media, "Estudios Mindonienses", 14 (1998), pp. 499-673.

${ }^{10} \mathrm{Gregoria}$ CAVERO DOMíngUEZ, Conflictos y revueltas contra la mitra asturicense, siglos XI$X V$, Ponferrada, 1996, p. 35.

${ }^{11}$ J.F. RIVERA RECIO, Notas sobre el episcopologio palentino de los siglos XIII y XIV, "Anuario de Estudios Medievales", 9 (1974-1979), pp. 407-424.

${ }^{12}$ Ángel BARrios GARCíA, Estructuras agrarias y de poder en Castilla. El ejemplo de Avila (1085-1320), Salamanca, 1983, p. 245.
} 
Ximeno, y que asistió al IV Concilio de Letrán de $1215^{13}$, tratándose de uno de los primeros ejemplos de miembros de esta familia con representación en la alta jerarquía eclesiástica abulense.

También podía suceder que en determinadas diócesis la titularidad de la mitra fuese acaparada frecuentemente por clérigos pertenecientes a destacadas familias de la sede metropolitana de la que dependía la diócesis en cuestión, que extendían así su ámbito de influencia dentro de la provincia eclesiástica. Ello se observa, por ejemplo, en Cuenca, donde a lo largo del siglo XIII nos encontramos con obispos emparentados entre sí y provenientes de algunas importantes familias de mozárabes toledanos, como los Juanes, Gudiel o Palomeque, que estaban a la cabeza de la oligarquía urbana de esta ciudad, y que previamente a su acceso a la mitra también habían ostentado alguna dignidad o canonjía en el cabildo catedralicio conquense ${ }^{14}$. Los Gudiel, por otro lado, y sin duda gracias al apoyo regio, también lograron que un destacado miembro de la familia - Don Gonzalo Pérez Gudiel - alcanzara la titularidad de la propia mitra toledana, donde sería arzobispo entre 1280 y 1298, sucediéndole en el cargo su sobrino y hasta entonces obispo de Cuenca Gonzalo Díaz Palomeque (1299-1310). Como es bien sabido, dada la destacada significación política de la sede toledana, algunos miembros de la Realeza llegarían incluso a ser titulares de la misma: tal fue el caso del infante don Sancho, hermano de Alfonso X, entre 1251 y 1261, y don Sancho de Aragón, hijo de Jaime I y cuñado del monarca castellano, entre 1266 y $1275^{15}$. Finalmente, no debemos olvidar mencionar a don Rodrigo Jiménez de Rada, destacada figura de la política y cultura castellana de la época, arzobispo de

\footnotetext{
${ }^{13}$ J.I. MORENO NÚÑEZ, Poder económico e influencia social de un clérigo castellano del siglo XIV: Sancho Sánchez, arcediano de Olmedo, "En la España Medieval”, 24 (2001), p. 397. Sobre el linaje de los Dávila puede verse el trabajo del mismo autor Los Dávila, linaje de caballeros abulenses. Contribución al estudio de la nobleza castellana en la baja Edad Media "En la España Medieval. Estudios en memoria del profesor Salvador de Moxó. II", Madrid, 1982, pp. 157-172.

${ }^{14} \mathrm{El}$ obispo conquense don Gonzalo Juanes (c 1230-1246) fue hermano del también obispo de Cuenca Rodrigo Juanes (1258-1261), siendo asimismo ambos tíos por vía materna de don Gonzalo Pérez Gudiel (1273-1275), que hasta entonces había sido arcediano de Moya. Otros obispos de origen mozárabe fueron Gonzalo García Gudiel (1280-1288), previamente arcediano de Cuenca, y Gonzalo Díaz Palomeque (1289-1299), hasta entonces canónigo conquense y emparentado con Gonzalo Pérez Gudiel. Jorge DíAZ IBÁÑEZ, Iglesia, sociedad y poder en Castilla. El obispado de Cuenca en la Edad Media (siglos XII-XV), Cuenca, 2003, pp. 79-90.

${ }^{15}$ Vid. J.F. RIVERA RECIO, Los arzobispos de Toledo en la baja Edad Media (s. XII-XV), Toledo, 1969.
}

«Anuario de Estudios Medievales», 35/2 (2005), pp. 557-603.- ISSN 0066-5061. 
Toledo entre 1209 y 1247, y procedente asimismo de una familia noble con ascendientes navarros y castellanos ${ }^{16}$.

Para el caso de las diócesis andaluzas restauradas tras los grandes avances reconquistadores de Fernando III, hay que destacar una importante presencia de prelados procedentes de linajes que se habían mostrado como estrechos colaboradores de la Realeza en las empresas político-militares. Así, durante el siglo XIII algunos de estos obispos pertenecerán a familias de hidalgos de las oligarquías urbanas, tal como sucedió en Jaén ${ }^{17}$ y en Córdoba. En esta última diócesis pueden señalarse los ejemplos de los obispos Lope de Fitero (1237-1245) y Gutierre Ruiz de Olea (1246-1249), ambos procedentes de familias de hidalgos de Burgos; Lope Pérez de Retes (1252-1257) o Fernando de Mesa (1257-1274), también de familias de la mediana nobleza. A partir de ahora la mayoría de los obispos de Córdoba procederán de linajes de la mediana nobleza cordobesa o andaluza ${ }^{18}$. Por otro lado, en Sevilla nos encontramos como procurador al frente del arzobispado, entre 1249 y 1259, al infante don Felipe, hijo de Fernando III. Sin embargo en las diócesis extremeñas -Plasencia, Coria y Badajoz-, si bien lo más habitual durante esta época, aunque no la norma, será el origen local del Episcopado, todavía los obispos de procedencia nobiliaria no tendrán la destacada presencia que sí que poseerán posteriormente ${ }^{19}$.

Con todo, para esta primera época que venimos analizando, carecemos de información sobre la extracción social de gran parte del Episcopado castellano. Así, las investigaciones de José Manuel Nieto para los años 1252-1312, señalan que de los aproximadamente 90 prelados castellanos del mencionado periodo, sólo disponemos de datos realmente fiables sobre la extracción social de unos 30 de ellos. Dentro de estos últimos, según el mencionado autor, se podrían diferenciar dos sectores sociales de donde

\footnotetext{
${ }^{16}$ Don Rodrigo había nacido hacia 1170 en Puente La Reina, Navarra, en el seno de una familia noble formada por navarros y castellanos. Sus ascendientes por línea paterna eran navarros, mientras que su madre, Eva de Finojosa, tenía ascendientes nobiliarios castellanos y era señora de Bliecos y Boñices, en Soria. R. JIMÉNEZ DE RADA, Historia de los Hechos de España, introducción de J. FERNÁNDEZ VALVERDE, Madrid, 1989, p. 16.

${ }^{17}$ José RoDRíGUEZ MOLINA, El obispado de Baeza-Jaén. Organización y economía diocesanas (siglos XIII-XVI), Jaén, 1986, p. 105.

${ }^{18}$ Iluminado SANZ SANCHO, Episcopologio medieval cordobés. Siglos XIII y XIV, "Hispania Sacra", 54 (2002), pp. 26-33.

${ }^{19}$ José Luis MARTín MARTín, Los obispos de Extremadura en la Edad Media, "Revista de Estudios Extremeños”, 47 (1991), pp. 74-76.
} 
proceden habitualmente los prelados: las oligarquías locales y las familias vinculadas a la Realeza. En torno a un $48 \%$ de los mencionados obispos procederían de oligarquías locales de base tanto rural como urbana, con unos importantes ingresos económicos y cuyos miembros tendían a emparentarse con otros grupos de poder vecinos. Además, en las familias de procedencia urbana, muchos de sus integrantes ejercieron puestos de relieve en el ámbito concejil, como alcalde o alguacil, transmitiéndolos de padres a hijos, debiendo ser destacado también el hecho de que para el mencionado período una notable mayoría de las oligarquías urbanas de donde salieron obispos castellanos se situaban en las ciudades de Toledo y Burgos ${ }^{20}$.

Por otro lado, el restante $52 \%$ de la treintena de obispos cuya extracción social se conoce procedería de familias vinculadas a la Monarquía, pudiendo distinguirse dentro de este grupo a prelados pertenecientes a la propia familia real y a aquellos otros que venían de linajes muy estrechamente vinculados con los monarcas mediante la prestación de servicios diversos. Las sedes episcopales con una más destacada presencia de obispos cuyas familias estaban vinculadas a la corona fueron tres: Toledo, donde encontramos como arzobispos a los dos infantes don Sancho, de Castilla y de Aragón, y, ya a comienzos del siglo XIV, a don Gutierre Gómez, cuyos parientes servían a la corona; Sigüenza, con los obispos Pedro de Orozco, Lope Díaz de Haro y Simón Girón de Cisneros, procedentes todos ellos de familias muy dedicadas al servicio real, algo que, en este caso concreto, resultaba especialmente conveniente a la corona puesto que los obispos de Sigüenza eran también señores de la ciudad y su término; y Palencia, también señorío episcopal, donde tres de los diez obispos de este período venían de linajes tradicionalmente dedicados al servicio real. Finalmente, aunque no se trata propiamente de una sede episcopal, habría que mencionar también, por la proyección política de sus titulares, la abadía de Valladolid, donde dos de los ocho abades del período fueron familiares del rey y otro perteneció a linajes tan vinculados a la corona como fueron los Manrique y Villalobos ${ }^{21}$. Es necesario insistir en que estas conclusiones están basadas en el estudio de la extracción social de algo menos de la mitad de los obispos castellanos del período 1252-1312, pues

${ }^{20}$ J.M. NIETO SORIA, Las relaciones Monarquía-Episcopado castellano como sistema de poder (1252-1312), Madrid, 1983, I, pp. 474-475.

${ }^{21}$ Ibid., I, pp. 476-478. Los Villalobos eran uno de los más importantes linajes castellanos de ricos-hombres, representativo de la vieja nobleza. Salvador de Moxó, Repoblación y sociedad en la España cristiana medieval, Madrid, 1979, p. 410.

«Anuario de Estudios Medievales», 35/2 (2005), pp. 557-603.- ISSN 0066-5061. 
para el resto los datos sobre sus orígenes familiares son inciertos o simplemente inexistentes.

Durante los siglos XIV y XV, época para la que disponemos de una mayor y mejor información documental, la expansión nobiliaria permitirá la consolidación del proceso que venimos señalando, y serán mucho más numerosos los linajes de la mediana o alta nobleza con una determinada representación -de mayor o menor importancia, según los casos-, dentro del Episcopado, en el cual se apoyará frecuentemente la Monarquía, paradójicamente, en muchos de sus enfrentamientos y conflictos con esa misma nobleza que nutría buena parte de la alta jerarquía eclesiástica.

Al llegar el siglo XV, nos encontramos con que los principales linajes de esta nobleza nueva, en torno a dos docenas, se habían diversificado en diversas líneas familiares o "casas", a veces con sus propios títulos. Cada gran casa noble tenderá a concentrar lo más importante de su poder en un marco regional, aunque algunos grandes linajes extendieron su poder a la práctica totalidad del reino. Varios de estos linajes de la nobleza nueva conseguirán acceder a los más altos puestos de la jerarquía eclesiástica castellana, amén del control que también ejercieron sobre los más importantes cargos de la administración estatal al servicio de la Monarquía.

En las tierras interiores del norte peninsular, los Manrique se hicieron fuertes en Álava y La Rioja, donde también tuvieron una importante presencia los Velasco, condes de Haro y condestables de Castilla. Otros linajes muy asentados en las regiones septentrionales fueron los Quiñones, condes de Luna, al norte de León; los Enríquez, linajes surgido de la Realeza, en torno a Valladolid; los Pimentel, condes de Benavente; o los Álvarez de Toledo, duques de Alba, en torno a la sierra de Gredos ${ }^{22}$.

Situándonos ya al sur del Sistema Central, uno de los linajes de ricoshombres con más peso fue el de los Mendoza, con varias casas, entre las que destacan las de los duques del Infantado y marqueses de Santillana, así como la de los condes de Tendilla; sus principales señoríos estaban en torno a Guadalajara y Madrid. Cercanos estaban los La Cerda, condes y luego duques de Medinaceli. Los Silva eran condes de Cifuentes; los Acuña condes de

${ }^{22}$ Miguel Ángel LADERo QUESADA, Los señores de Andalucía. Investigaciones sobre nobles y señoríos en los siglos XIII al XV, Cádiz, 1998, pp. 20-21.

«Anuario de Estudios Medievales», 35/2 (2005), pp. 557-603.- ISSN 0066-5061. 
Buendía; los Pacheco marqueses de Villena y duques de Escalona; y los Sotomayor condes de Belalcázar, ya en el norte de Córdoba ${ }^{23}$.

En la actual Extremadura destacarán los Zúñiga, Suárez de Figueroa, Portocarrero y los La Cueva, mientras que en Murcia uno de los linajes con más peso será el de los Fajardo. Finalmente, en Andalucía los linajes con una más importante presencia fueron los Guzmán, condes de Niebla y duques de Medina Sidonia; los Ponce de León, condes y luego duques de Arcos de la Frontera; los Téllez Girón, señores de Osuna; y las diversas ramas de los Fernández de Córdoba. Los Guzmán y los Ponce de León concentraron su poder en el reino de Sevilla, y los Fernández de Córdoba en el de Córdoba. En el reino de Jaén hubo pequeños caballeros, pero apenas grandes linajes, al estar bloqueada su expansión por los señoríos de las Órdenes Militares de Santiago y Calatrava y de la mitra arzobispal de Toledo ${ }^{24}$.

Comenzaremos analizando la presencia de prelados de procedencia noble en las diócesis del norte peninsular. Primeramente, en la archidiócesis de Santiago de Compostela, durante el siglo XIV figuran al frente de la mitra personajes de origen nobiliario como don Gómez Manrique (1351-1362), don Suero Gómez de Toledo (1362-1366) o don Juan García Manrique (13821399), sobrino de don Gómez ${ }^{25}$. Ya en el siglo XV encontraremos arzobispos provenientes de linajes nobles bastante ramificados, pero que fijan su atención en Galicia, donde cada prelado se asentará con muchos de sus parientes y familiares dejando en ella una casa nobiliaria bien instalada. Los arzobispos del XV y principios del XVI fueron Lope de Mendoza (1400-1445); Álvaro Núñez de Isorna (1445-1449); Rodrigo de Luna (1449-1460); y los tres prelados Fonseca: Alonso de Fonseca I "el Viejo" (1460-1464), Alonso de Fonseca II (1464-1506), y Alonso de Fonseca III (1506-1523) ${ }^{26}$. Estos últimos son claros exponentes de una familia de la nobleza media-baja, en su origen modestos hidalgos procedentes de Portugal que emigraron a Castilla tras la implantación de la dinastía Avís, y que a la sombra de la Corona castellana ascienden vertiginosamente desde mediados del $\mathrm{XV}$, con representantes en numerosos ámbitos de la jerarquía eclesiástica y civil del reino, llegando

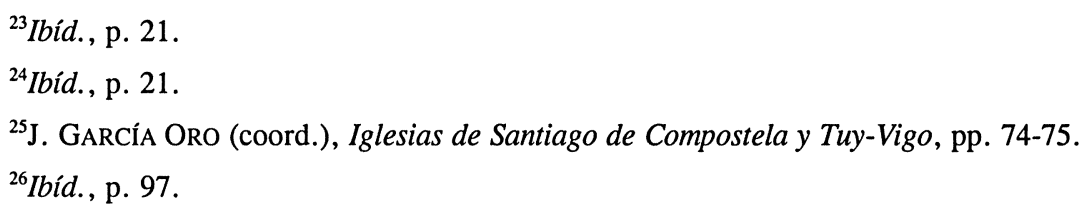


incluso a transmitirse importantes cargos eclesiásticos entre los miembros del linaje ${ }^{27}$.

El primer Alonso de Fonseca, gran colaborador de Enrique IV, llevaría a su familia al protagonismo señorial gallego; entre 1445 y 1454 fue obispo de Ávila, desde donde pasó a Sevilla, y de 1460 hasta 1464 a Santiago, para regir nuevamente Sevilla entre 1464 y 1473. El siguiente Alonso de Fonseca, sobrino del anterior, fue titular de la mitra hispalense entre $1460 \mathrm{y}$ 1464, para pasar este último año a Santiago, diócesis que gobernó hasta 1506. Finalmente, el último prelado Fonseca, bastardo del anterior, fue arzobispo de Santiago entre 1506 y 1523 , y desde este último año hasta 1534 arzobispo de Toledo ${ }^{28}$. Hubo, además, otros obispos Fonseca que rigieron otras diócesis, como por ejemplo Alonso de Fonseca, sobrino de Alonso de Fonseca "el" Viejo", que fue sucesivamente obispo de Ávila, Cuenca y Osma en la segunda mitad del XV, y Juan Rodríguez de Fonseca, obispo de Badajoz (1495-1499) y Córdoba (el. 1499), capellán de Fernando el Católico y presidente del Consejo de Indias ${ }^{29}$.

En otras diócesis gallegas, como Mondoñedo, para el siglo XIV los únicos casos destacados de obispos nobles son Álvaro Pérez de Biedma (13291343), procedente de la nobleza media de Orense $e^{30}$, y Lope de Mendoza (1393-1399), de origen sevillano ${ }^{31}$; durante esta centuria hubo tanto prelados que accedieron al cargo procedentes del propio cabildo catedralicio mindoniense, como otros que llegaron desde otros lugares de Galicia o del reino. Durante el siglo $\mathrm{XV}$, sin embargo, el origen nobiliario medio-alto del Episcopado de Mondoñedo será mucho más predominante, pudiendo destacarse las figuras de Álvaro Núñez de Isorna (1399-1415), sobrino del anterior obispo mindoniense, don Francisco ${ }^{32}$; Pedro Enríquez de Castro

\footnotetext{
${ }^{27}$ A. Franco Silva, El arzobispo de Sevilla Alonso de Fonseca el Viejo. Notas sobre su vida, "Boletín de la Real Academia de la Historia", 196 (1999), pp. 44-45.

${ }^{28}$ Un pequeño estudio sobre estos tres prelados, con una amplia colección documental, puede verse en: José García Oro; $M^{\mathbf{a}}$ José PORTEla Silva, Los Fonseca en la Galicia del Renacimiento: de la guerra al mecenazgo, La Coruña, 2002. Una amplia información sobre la proyección sociopolítica de la Iglesia en la Galicia bajomedieval también queda recogida en J. GARCÍA ORO, Galicia en los siglos XIV y XV, 2 vols., Santiago, 1987.

${ }^{29}$ A. Franco Silva, op. cit., p. 45. Conrado Eubel, Hierarchia Catholica Medii Aevi, Monasterii, 1901-1913, II, pp. 152 y 232.

${ }^{30}$ E. CAL PARDo, Episcopologio mindoniense. Baja Edad Media, p. 574.

${ }^{31}$ Ibid., p. 602.

${ }^{32}$ Ibid., p. 606.
}

«Anuario de Estudios Medievales», 35/2 (2005), pp. 557-603.- ISSN 0066-5061. 
(1427-1445); Alonso Vázquez de Acuña (1455-1457), que era además sobrino del obispo de Jaén Gonzalo de Zúñiga; y don Fadrique de Guzmán (14571492), procedente de la nobleza sevillana ${ }^{33}$. Vemos cómo aquí tampoco faltan los vínculos familiares entre los prelados, casi todos ellos fieles servidores de la corona, y que frecuentemente también introducirían a algunos de sus parientes en el cabildo catedralicio mindoniense.

Por lo que respecta a la diócesis de Lugo, cabría destacar a algunos obispos procedentes de linajes gallegos como Álvaro Pérez Osorio (14341440) o García Martínez Bahamonde $(1440-1445)^{34}$, y también hay que mencionar al obispo franciscano Juan Enríquez (1409-1417), que era hijo del almirante Alfonso Enríquez y durante los tres años anteriores a su llegada a la diócesis de Lugo había sido Ministro Provincial de los franciscanos de Castilla $^{35}$. En Orense predominará una extracción nobiliaria media del Episcopado, con una importante representación de linajes gallegos como los Navoa, Biedma, Noya o Fonseca ${ }^{36}$, entre otros, sin que tampoco falte algún ejemplo de obispo procedente de la alta nobleza castellana, como fue don Juan García Manrique (1371-1375) ${ }^{37}$. Algo parecido sucederá en el obispado de Tuy, con una procedencia del Episcopado mayoritariamente de la nobleza media-baja, algunos de ellos gallegos ${ }^{38}$, pero también con algunos representantes de la alta nobleza castellana como los obispos Gómez Manrique (13481351) y Juan Ramírez de Guzmán (1390-1394) ${ }^{39}$.

El mencionado linaje Manrique, presente sobre todo desde mediados del siglo XIV tanto en algunas diócesis gallegas como en otros obispados del reino, potenciaría la carrera eclesiástica de algunos segundones e incluso bastardos del mismo, si bien aquí esta tendencia no será tan acusada como en el caso de los segundones de otros linajes. Casi todos los grandes eclesiásticos

${ }^{33}$ Ibid., p. 641.

${ }^{34}$ Conrado Eubel, Hierarchia Catholica Medii Aevi, II, p. 199.

${ }^{35}$ J.M. NIETO SORIA, Iglesia y génesis del Estado Moderno en Castilla (1369-1480), Madrid, 1993, p. 433.

${ }^{36}$ Ejemplo de ello son los obispos Gonzalo Núñez de Navoa (el. 1319), Álvaro Pérez de Biedma (1343-1351), Alfonso de Noya (1361-1366) y Diego de Fonseca (1470-1486). C. EUBEL, Hierarchia, I, p. 119; II, p. 112.

${ }^{37}$ C. EubEL, Hierarchia, I, p. 119.

${ }^{38}$ Por ejemplo, Juan Fernández de Sotomayor (1286-1323) y García Martínez Bahamonde (1437-1440), entre otros. Ibíd., I, p. 501; II, p. 283.

${ }^{39}$ Ibid., I, p. 501.

«Anuario de Estudios Medievales», 35/2 (2005), pp. 557-603.- ISSN 0066-5061. 
del linaje fueron capellanes reales y participaron en los principales organismos políticos del reino, protegiendo también a sus parientes y facilitando la rápida promoción de los que empezaban la carrera clerical ${ }^{40}$.

Saliendo ya del ámbito gallego, veamos a continuación cómo fue la representación nobiliaria entre el Episcopado de otras diócesis del norte de Castilla. Así, por ejemplo, en Astorga, mientras que en el siglo XIV la extracción social del Episcopado no será demasiado relevante, durante el siglo $\mathrm{XV}$, en cambio, tendremos a prelados procedentes de destacados linajes de la mediana e incluso alta nobleza, como fueron el cardenal Pedro de Fonseca (1413-1419) ${ }^{41}$, Sancho de Rojas (1423-1440), Álvaro Pérez Osorio (14401463), García Álvarez de Toledo (1463-1488) o Bernardino de Carvajal (1488-1489) $)^{42}$, entre otros.

En el obispado de Osma, durante la segunda mitad del XIV encontramos a algunos prelados de la mediana nobleza, como Pedro Gómez Barroso (1368-1373), Juan García Palomeque (sed. 1373), natural de Toledo, o el cardenal Pedro Fernández de Frías (1379-1404), mientras que otros obispos seguirán siendo originarios del ámbito regional soriano. En la siguiente centuria, en cambio, sí que habrá obispos procedentes de grandes linajes. Ejemplo de ello serán Lope de Mendoza (1404-1408); el cardenal Alonso Carrillo de Albornoz (1408-1422); Juan de Cerezuela y Luna (1422-1433), hermanastro de don Álvaro de Luna; Pedro de Castilla (1433-1440), natural de Soria e hijo del infante don Juan; el cardenal Pedro González de Mendoza (1482); y Alfonso de Fonseca (1493-1505) ${ }^{43}$.

En la diócesis de Calahorra, durante los siglos XIV y XV serán mayoría los prelados procedentes de la mediana nobleza, muchos de ellos relacionados con la corte regia o pontificia, aunque tampoco faltarán representantes de grandes linajes, como Juan Ramírez de Guzmán (1394-

\footnotetext{
${ }^{40}$ Rosa $\mathrm{M}^{\mathrm{a}}$ MonTERo Tejada, Nobleza y sociedad en Castilla. El linaje Manrique (siglos XIV-XVI), Madrid, 1996, pp. 289-298.

${ }^{41}$ Ibid., I, p. 114.

${ }^{42} \mathrm{G}$. CAVERo DomíngueZ, Conflictos y revueltas contra la mitra asturicense, p. 35.

${ }^{43}$ T. PORTILlo CAPILla, Episcopologio oxomense-soriano (597-1997), “Celtiberia”, 91 (1997), pp. 19-23. Este episcopologio contiene algunas inexactitudes que hemos corregido con los datos de C. EuBEL, Hierarchia, I, p. 383; II, p. 231.

«Anuario de Estudios Medievales», 35/2 (2005), pp. 557-603.- ISSN 0066-5061.
} 
1403), Diego López de Zúñiga (1408-1443) o el futuro cardenal Pedro González de Mendoza (1453-1467) ${ }^{44}$.

Burgos también es otro obispado en el que, aunque predominaron los prelados cuya extracción social se situaba en la baja o mediana nobleza, así como algún destacado linaje judeoconverso - los García de Santa Maríasobre el que hablaremos más adelante, en ocasiones también encontraremos ostentando la titularidad de la mitra a algunos miembros de importantes linajes de la alta nobleza, siendo ejemplo de ello los obispos Gonzalo Osorio (1313$1327)^{45}$, Juan García Manrique (1381-1382) ${ }^{46}$ y Luis de Acuña y Osorio $(1456-1495)^{47}$.

Por lo que respecta a la diócesis palentina, durante el siglo XIV coexistirán las provisiones episcopales realizadas por el papa a favor de algún candidato extranjero (francés) con los nombramientos de prelados castellanos, bastantes de origen noble, como por ejemplo el ya citado Álvaro Gómez Carrillo (1297-1305), Vasco Fernández de Toledo (1343-1353), o el cardenal Gutierre Gómez de Toledo $(1357-1381)^{48}$, mientras que en el XV, junto a prelados de la mediana nobleza -entre ellos Gutierre de la Cueva (14611469), hermano de Beltrán de la Cueva—, también encontraremos obispos de destacados linajes de la alta nobleza como Rodrigo Velasco (1417-1423), Gutierre Álvarez de Toledo (1423-1439) ${ }^{49}$ o Diego Hurtado de Mendoza (1470-1485), además de Pedro de Castilla (1440-1461), hijo del infante don $\mathrm{Juan}^{50}$.

Precisamente el citado linaje de los Toledo fue uno de los que tuvo mayor proyección eclesiástica durante el siglo XIV, y de él saldrán importantes prelados de otras diócesis castellanas, pudiendo hablarse casi de la constitución de una dinastía episcopal. Así, el mencionado Vasco Fernández de Toledo, tras ocupar durante una década la sede palentina pasaría a ser

\footnotetext{
${ }^{44}$ E. SÁINZ RIPA, Los obispos de Calahorra en la Edad Media (siglos VIII-XV), "I Semana de Estudios Medievales de Nájera (6-11 de agosto de 1990)", Logroño, 2001, pp. 59-60.

${ }^{45}$ Conradum Eubel, Hierarchia Catholica Medii Aevi, I, p. 151.

${ }^{46}$ Ibid., p. 151.

${ }^{47}$ J.M. NiETO SORIA, Iglesia y génesis, p. 421. 407-424.

${ }^{48}$ J.F. RIVERA RECIO, Notas sobre el episcopologio palentino de los siglos XIII y XIV, pp.

${ }^{49}$ C. Eubel, Hierarchia Catholica Medii Aevi, I, p. 386.

${ }^{50}$ Ibíd., II, p. 232.

«Anuario de Estudios Medievales», 35/2 (2005), pp. 557-603.- ISSN 0066-5061.
} 
arzobispo de Toledo, mitra de la que fue titular desde 1353 a 1362 . Un antepasado suyo, Gutierre Gómez de Toledo, ya había sido titular de la sede primada entre 1311 y 1319 . Todo ello, en definitiva, debe ser puesto en estrecha relación con la importante posición que este linaje ocupaba dentro de la oligarquía urbana de Toledo, extendiéndose además la proyección eclesiástica del linaje a otras diócesis sufragáneas de la sede primada, tal como sucedió en Palencia. Otro eximio representante del linaje, homónimo del prelado recién mencionado, fue Gutierre Gómez de Toledo, obispo de Oviedo entre 1377 y 1389, que tampoco debe ser confundido con su homónimo tío y obispo de Palencia al que ya se ha hecho referencia, ni con su primo del mismo nombre que fue prior castellano de la Orden de San Juan de Jerusalén, muerto en 1364. El mencionado Gutierre Gómez, obispo ovetense, tenía además ciertos vínculos de parentesco con el arzobispo de Toledo don Pedro Tenorio (1377-1399). Finalmente, habría que destacar la gran proyección política y señorial que, tanto a nivel eclesiástico como civil, tuvo el linaje de los Toledo ${ }^{51}$.

En la diócesis de Oviedo, además de don Gutierre Gómez, y junto a un buen número de prelados procedentes de la mediana o baja nobleza castellana, entre los que destacaría Rodrigo Sánchez de Arévalo (1457-1467), también encontraremos a algunos representantes de grandes linajes como fueron los obispos Guillermo García Manrique (1389-1397), Diego Ramírez de Guzmán (1412-1441), García Enríquez Osorio (1441-1442) o Iñigo Manrique de Lara (1444-1457) ${ }^{52}$.

Un grupo de diócesis del centro-norte de Castilla con un Episcopado claramente representativo en cuanto a su extracción social de la mediana y baja nobleza del reino será el constituido por los obispados de Salamanca, Ciudad Rodrigo, Zamora y León. En Ciudad Rodrigo, donde hubo varios

${ }^{51}$ F.J. FERNÁNDEZ CONDE, Gutierre de Toledo, obispo de Oviedo (1377-1389). Reforma eclesiástica en la Asturias bajomedieval, Oviedo, 1978, pp. 30-31. El obispo ovetense y muchos de sus familiares, incluidos los no eclesiásticos, desempeñaron importantes cargos en la política regia. Otros destacados miembros del linaje fueron García Álvarez de Toledo, maestre de Santiago y primer señor de Valdecorneja, y Fernán Álvarez de Toledo, segundo señor de Valdecorneja. Por otro lado, dos antepasados del obispo de Oviedo, García Álvarez y Gutierre Fernández de Toledo, descendían de los primeros titulares del condado de Alba de Tormes, que con el tiempo llegaría a ser la poderosa casa de los duques de Alba. Ibíd., p. 34.

${ }^{52} \mathrm{C}$. EuBEL, Hierarchia, I, p. 382; II, p. 231. Hubo también en Oviedo algún representante de linajes gallegos, como el obispo Juan Arias (1487-1498), así como un miembro de la familia conversa de los Santa María de Burgos: nos referimos al obispo Juan Díaz de Coca (1467-1469), sobrino del obispo de Burgos don Pablo de Santa María.

«Anuario de Estudios Medievales», 35/2 (2005), pp. 557-603.- ISSN 0066-5061. 
titulares de la mitra pertenecientes a órdenes mendicantes ${ }^{53}$, incluso habrá algún prelado de baja extracción social. En las demás diócesis mencionadas encontraremos representantes de linajes como, entre otros muchos, los Anaya $^{54}$, Vivero ${ }^{55}$, Deza $^{56}$, Carvajal $^{57}$, Valdés ${ }^{58}$, Osorio ${ }^{59}$, Isorna ${ }^{60}$. Especialmente relevante resulta la presencia de linajes gallegos como los Vivero, Osorio e Isorna que, por proximidad geográfica, extendían su ámbito de influencia a estas diócesis, entre otras. Finalmente, no faltarán algunos prelados procedentes de la alta nobleza castellana, como fueron los obispos de León Diego Ramírez de Guzmán (1344-1354) ${ }^{61}$, Luis de Velasco (14781484) e Iñigo Manrique de Lara (1484-1485) ${ }^{62}$.

Centrándonos a continuación en el obispado de Ávila, hay que señalar que durante el siglo XIV, al igual que sucedió en la centuria anterior, también encontraremos ocupando la sede a un representante del importante linaje de los Dávila de Ávila, señores de Navamorcuende-Cardiel, auténtica oligarquía urbana abulense en el ámbito concejil que también tuvo una importante proyección en el terreno eclesiástico. Se trata de Sancho Blázquez, hermano del alcalde de la ciudad Fernán Blázquez, y obispo de Ávila entre 1312 y 1355, que fue también notario mayor de Castilla (1313-1320) y canciller mayor (1325-1326); fue además señor de Villatoro, cuyo mayorazgo fundó en 1328. Gracias a la titularidad de la diócesis que ostentó durante más de

\footnotetext{
${ }^{53}$ Ibid., I, p. 189; II, p. 144.
}

${ }^{54} \mathrm{Tal}$ es el caso de Diego de Anaya y Maldonado, obispo de Salamanca (1392-1407). C. EUBEL, $o p$. cit., I, p. 429.

${ }^{55}$ Ejemplo de ello sería el también obispo salmantino Gonzalo de Vivero (1447-1482), procedente de un linaje de la nobleza gallega. Ibid., II, p. 250.

${ }^{56}$ Como Diego de Deza, obispo de Zamora (1494) y Salamanca (1494-1498). Ibíd., II, pp. 250 y 298.

${ }^{57}$ Como miembro de este linaje extremeño podemos mencionar al cardenal Juan de Carvajal, nombrado titular de la mitra de Zamora a fines de 1467, aunque poco después haría resignación del cargo. Ibíd., II, p. 298.

${ }^{58}$ Tal es el caso de Diego Meléndez Valdés, obispo de Salamanca (1483-1491) y de Zamora (el. 1494). Ibíd., II, pp. 250 y 298.

${ }^{59}$ Como el obispo de León Gonzalo Osorio y Villalobos (1301-1313), de linaje gallego. Ibíd., I, p. 299.

${ }^{60} \mathrm{~A}$ este linaje, también gallego, pertenecía el obispo de León Álvaro Núñez de Isorna (14151418). Ibíd., I, p. 300.

${ }^{61}$ Ibid., I, p. 300.

${ }^{62}$ Ibid., II, p. 193.

«Anuario de Estudios Medievales», 35/2 (2005), pp. 557-603.- ISSN 0066-5061. 
cuarenta años, el obispo don Sancho consiguió introducir en el cabildo abulense a algunos de sus parientes, siendo ejemplo de ello sus sobrinos-nietos Sancho Sánchez, canónigo y arcediano de Olmedo desde 1338, y el igualmente canónigo Fernán Blázquez ${ }^{63}$. La extracción social del resto de los obispos abulenses de los siglos XIV y XV se situará, por lo general, en la mediana o baja nobleza castellana ${ }^{64}$, aunque también habrá algunos miembros de grandes linajes como los obispos Juan Ramírez de Guzmán (1403-1424), Alonso de Fonseca (1445-1454), otro Alonso de Fonseca (1469-1485) y Alonso Carrillo (el. 1496) ${ }^{65}$.

Una situación que merece particular atención es la referente a los obispos originarios de linajes de judeoconversos. El caso más relevante probablemente sea el de los García de Santa María, de Burgos. Don Pablo de Santa María (1353-1435) había sido rabino de la aljama burgalesa, y en 1390 se convirtió al Cristianismo, realizando una brillante carrera eclesiástica; fue capellán y consejero real en la Corte, su linaje se afianzó dentro de la oligarquía urbana burgalesa, y llegaría a ser obispo de Cartagena desde 1403 y de Burgos desde 1415, gracias al favor de Benedicto XIII. Su hermano, Alvar García de Santa María, se integró también en la Corte y en el concejo burgalés, y fue administrador del obispado de Cartagena por nombramiento de don Pablo. A partir de ahora se desarrollará un entramado familiar que controlará instituciones concejiles, eclesiásticas y algunos puestos en la administración central. Así, el hijo mayor del obispo don Pablo, Gonzalo García de Santa María (o de Cartagena), sería sucesivamente obispo de Astorga (1419-1423), Plasencia (1423-1446) y Sigüenza (1446-1448).

Pero el prelado más destacado del linaje fue el conocido escritor Alonso García de Santa María, más conocido como Alonso de Cartagena (1385-1456), segundo hijo del antiguo rabino y obispo don Pablo, y que, como su padre, también fue consejero real, sucediéndole como obispo de Burgos en 1435, cargo que ocuparía hasta su muerte, y desde el que encabezó

${ }^{63}$ J.I. MORENO NÚÑEZ, Poder económico e influencia social de un clérigo castellano del siglo XIV: Sancho Sánchez, arcediano de Olmedo, pp. 398-399. Sobre el obispo don Sancho Blázquez puede verse el trabajo del mismo autor Semblanza y patrimonio de don Sancho Blázquez, obispo de Ávila (1312-1355), "Hispania Sacra”, 37 (1985), pp. 155-188.

${ }^{64}$ Como ejemplo de ello podemos citar, entre otros, a los obispos Alfonso de Egea (13951403) y Fray Lope de Barrientos (1441-1445). J.M. NIETO SORIA, Iglesia y génesis, pp. 426 y 432.

${ }^{65}$ C. Eubel, Hierarchia, I, p. 67; II, p. 88. 
una tupida red de relaciones clientelares ${ }^{66}$. Otro prelado de la familia fue Juan Díaz de Coca (1389-1477), sobrino del obispo don Pablo de Santa María, que tras ser deán de Burgos obtendría en 1467 la titularidad de la mitra de Oviedo, pasando en 1470 a ser obispo de Calahorra ${ }^{67}$. Asimismo otro sobrino, por parte de madre, del obispo don Pablo, sería Alfonso Rodríguez Maluenda, canónigo de Burgos, abad de Valladolid y obispo electo de Salamanca en 1447, cargo este último del que no llegaría a tomar posesión, mientras que su pariente Juan Ortega Maluenda conseguiría llegar a obispo de Coria ${ }^{68}$. En el último tercio del siglo nos encontraremos también con otro obispo vinculado al linaje, el dominico Fray Alonso de Burgos, que ocupó sucesivamente las sedes de Córdoba (1477-1482), Cuenca (1482-1485) y Palencia (1485-1499) ${ }^{69}$. Finalmente, dentro de la estrategia de ascenso social de los García de Santa María (o Cartagena) habría que destacar su emparentamiento, ya avanzado el siglo XV, con una rama del poderoso linaje Mendoza, de enorme proyección eclesial $^{70}$.

Otra importante familia de conversos con proyección eclesiástica durante el siglo XV fue la de los Arias Dávila de Segovia. Diego Arias Dávila, patriarca del clan, casado con Elvira González, a pesar de ser un reciente converso, en 1440 representó a Segovia en un sínodo diocesano, y dos años más tarde fundó el hospital de San Antonio de Padua en Segovia, pero se sospecha que judaizaba ${ }^{71}$. Juan Arias Dávila, hijo segundo de ambos, fue canónigo y deán segoviano, oidor de la Audiencia Real desde 1458, capellán de Enrique IV y, finalmente, obispo de Segovia (1461-1497) a petición del monarca castellano, lo que sin duda beneficiaba enormemente los

\footnotetext{
${ }^{66}$ Luis FERNÁNDEZ GALLARDO, Alonso de Cartagena (1385-1456). Una biografía política en la Castilla del siglo XV, Valladolid, 2002, pp. 15-34. Un amplio cuadro genealógico del linaje se encuentra recogido en la Real Academia de la Historia, Colección Salazar, O-19, f. 251v. Sobre los García de Santa María hay que destacar ante todo el trabajo de Francisco CANTERA BuRgos, Alvar García de Santa María y su familia de conversos. Historia de la judería de Burgos y de sus conversos más egregios, Madrid, 1952.

${ }^{67} \mathrm{~F}$. CANTERA BURGOS, op. cit., p. 369.

${ }^{68}$ Ibíd., pp. 388-390.

${ }^{69}$ J.M. NIETO SORIA, Iglesia y génesis, pp. 427-428.

${ }^{70}$ F. CANTERA Burgos, op. cit., p. 58 (genealogía de los García de Santa María).

${ }^{71}$ David. M. GITLITZ, Los Arias Dávila de Segovia. Entre la sinagoga y la Iglesia, San Francisco, 1996, p. 23
}

«Anuario de Estudios Medievales», $35 / 2$ (2005), pp. 557-603.- ISSN 0066-5061. 
intereses sociales y económicos de un linaje de orígenes conversos ${ }^{72}$. Por lo demás, la extracción social de los obispos segovianos se situará generalmente en la mediana nobleza castellana, o local segoviana, con algún representante de la alta nobleza como el obispo Luis de Acuña y Osorio (1449-1456) ${ }^{73}$.

La archidiócesis toledana, dado su carácter de sede primada y enorme proyección política, estará casi siempre ocupada por conspicuos representantes de los más importantes linajes de la nobleza castellana, o a veces aragonesa (tal como sucedió con el linaje de los Luna, emparentados con los Albornoz). Incluso, tal como ya había sucedido durante el siglo XIII, también encontraremos a algún miembro de la realeza aragonesa como titular de la mitra: es el caso de don Juan, infante de Aragón, que fue arzobispo de Toledo entre 1319 y 1328. De este modo, para los siglos XIV y XV, podríamos citar los siguientes ejemplos, algunos de ellos ya señalados con anterioridad, de destacados miembros de grandes linajes nobiliarios que ostentaron la titularidad de la sede primada toledana: Gutierre Gómez de Toledo (13111319); Jimeno de Luna (1328-1338); Gil Álvarez de Albornoz (1338-1350); Vasco Fernández de Toledo (1353-1362); Gómez Manrique (1362-1375); Pedro Tenorio (1377-1399); Pedro de Luna (1403-1414), sobrino del papa Benedicto XIII; Juan de Cerezuela y Luna (1434-1442); Gutierre Álvarez de Toledo (1442-1445); Alfonso Carrillo de Acuña (1446-1482); y el cardenal Pedro González de Mendoza (1482-1495) ${ }^{74}$.

La diócesis de Cuenca podría considerarse otro ejemplo de sede episcopal en la que la extracción social de la mayoría los prelados durante las dos últimas centurias de la Edad Media se sitúa en la nobleza media castellana, pudiendo citarse a este respecto, entre otros muchos, ejemplos de obispos como Gonzalo Pérez de Aguilar (1341-1342), Nicolás Fernández de Biedma (1378-1381), Juan Fernández Cabeza de Vaca (1396-1407), Diego de Anaya Maldonado (1407-1418) o Álvaro Núñez de Isorna (1418-1445) ${ }^{75}$. También debe destacarse la presencia en Cuenca del obispo Fray Alonso de

\footnotetext{
${ }^{72} \mathrm{Ibíd}$, p. 68. Otro miembro del linaje fue el protonotario apostólico segoviano Diego Arias Dávila, nombrado también capellán regio en 1459. Ibíd., p. 104.

${ }^{73}$ C. EUBEL, Hierarchia, II, p. 258.

${ }^{74}$ Vid. J.F. RIVERA RECIO, Los arzobispos de Toledo en la baja Edad Media (s. XII-XV).

${ }^{75}$ Vid. mi libro Iglesia, sociedad y poder en Castilla. El obispado de Cuenca en la Edad Media, pp. 97-111.
}

«Anuario de Estudios Medievales», 35/2 (2005), pp. 557-603.- ISSN 0066-5061. 
Fonseca (1485-1493) ${ }^{76}$, representante del ya citado linaje episcopal de los Fonseca. No hubo en Cuenca, a pesar de algunos intentos, obispos de origen local $^{77}$, pero en cambio en el cabildo catedralicio, según se verá más adelante, sí que encontraremos a miembros de grandes linajes como los Albornoz, Mendoza o Carrillo, bien asentados en tierras conquenses.

Estos tres últimos linajes sí que conseguirán acceder a la titularidad de la mitra episcopal de Sigüenza, donde también habrá prelados de otras importantes familias de la alta y mediana nobleza castellana. Así, durante los siglos XIV y XV encontraremos al frente de la diócesis a obispos procedentes de destacados linajes, como Simón Girón de Cisneros (1300-1326) ${ }^{78}$; Gonzalo de Aguilar (1342-1348) ${ }^{79}$; Pedro Gómez Barroso de Albornoz (1348-1358) ${ }^{80}$; Juan García Manrique (1376-1381), cuya madre era sobrina del arzobispo de Toledo don Gómez Manrique ${ }^{81}$; el cardenal Pedro de Fonseca (1419-1422) ${ }^{82}$; el también cardenal Alonso Carrillo de Albornoz (1422-1434) ${ }^{83}$; Alonso Carrillo de Acuña (1435-1446) ${ }^{84}$; Gonzalo García de Santa María, de la citada familia judeoconversa de Burgos (1446-1448) ${ }^{85}$; el cardenal Pedro González de Mendoza (1467-1495), también titular de la sede primada ${ }^{86}$; y Bernardino López de Carvajal (1495-1511), procedente de la nobleza extremeña ${ }^{87}$.

${ }^{76} I b i d .$, p. 126.

${ }^{77}$ En 1326 y 1327 el cabildo catedralicio conquense eligió como obispo de la diócesis al joven Gil Álvarez de Albornoz -el futuro cardenal-, representante de la alta nobleza local, siendo finalmente anulada en ambos casos dicha elección por el papa alegando defecto de edad del candidato. Por otro lado, ya en el último tercio del siglo XV, concretamente en 1469, el cabildo eligió como prelado al noble conquense Juan Hurtado de Mendoza, pero tampoco en esta ocasión prosperó la elección, puesto que el nuevo obispo sería finalmente el candidato pontificio y cardenal Antonio Jacobo de Veneris. Ibíd., pp. 152-154.

${ }^{78}$ Este prelado era hijo de Ruy González de Cisneros, señor del linaje Cisneros, y de doña Elvira de Saldaña. T. MiNGUELla ARNEDO, Historia de la diócesis de Sigüenza y de sus obispos, Madrid, 1912, II, p. 1.

${ }^{79}$ Ibid., p. 51.

${ }^{80}$ Ibid., p. 58.

${ }^{81}$ Ibid., p. 75.

${ }^{82}$ Ibid., p. 121.

${ }^{83}$ Ibid., p. 125.

${ }^{84}$ Ibid., p. 132.

${ }^{85}$ Ibid., p. 143.

${ }^{86}$ Ibid., p. 169.

${ }^{87}$ Ibid., p. 197.

«Anuario de Estudios Medievales», 35/2 (2005), pp. 557-603.- ISSN 0066-5061. 
Precisamente en las tres diócesis extremeñas -Plasencia, Coria y Badajoz-, lo más habitual, aunque no la norma, fue que la extracción social de los obispos correspondiese a linajes locales que utilizaban la mitra y cabildos catedralicios como forma de promoción social, tal como sucedió con familias como los Suárez de Figueroa, Zúñiga, Carvajal o Dávila, aunque desde mediados del siglo XV los segundones de linajes nobles extremeños tenderán a optar menos por la carrera eclesiástica ${ }^{88}$. Hay que destacar el hecho de que en estas diócesis, desde el siglo XIII al XV, hay hasta 21 casos documentados de obispos frailes o monjes, algunos de los cuales también pertenecieron a familias de la mediana nobleza extremeña ${ }^{89}$. No faltarán, sin embargo, representantes de otros linajes castellanos con proyección eclesiástica, siendo ejemplo de ello los obispos de Badajoz Juan Palomeque (13541373) y Juan Fonseca (1495-1499); el obispo de Coria Iñigo Manrique de Lara (1457-1475); y los obispos de Plasencia Gonzalo García de Santa María (1423-1446) y Gutierre de Toledo (1496-1506) ${ }^{90}$.

Por lo que respecta a la sede de Cartagena, durante los dos últimos siglos del Medievo estará regida fundamentalmente por obispos cuya extracción social se sitúa sobre todo en linajes de la mediana nobleza castellana, con frecuencia vinculados a la Monarquía, pero con escasa representación de la nobleza local de la diócesis. Hay que recordar que el judeoconverso Pablo de Santa María fue obispo de esta diócesis entre 1403 y 1415, año de su traslado a Burgos. Un caso que merece especial mención es el del cardenal Rodrigo de Borja, elegido como papa Alejandro VI en 1492, y que fue titular de la sede de Cartagena desde 1482 hasta el año de su elección como máximo pontífice ${ }^{91}$.

\footnotetext{
${ }^{88}$ Algunos linajes, como los Carvajal, impulsaron a sus hijos segundones a escoger la carrera eclesiástica, usando luego la vía del nepotismo y clientela para colocar a otros miembros del linaje. En todo caso, la mayoría de los nobles extremeños optaban por las carreras militar y civil, y sólo algunos segundones se inclinarán, a veces por imposición del linaje, hacia la vía eclesiástica. Marie Claude GERBET, La nobleza en la corona de Castilla. Sus estructuras sociales en Extremadura (1454-1516), Cáceres, 1989, pp. 169-170.

${ }^{89}$ J.L. MARTín MARTín, Los obispos de Extremadura en la Edad Media, pp. 74-76. Como ejemplos de prelados procedentes de los mencionados linajes extremeños podríamos citar a Lorenzo Suárez de Figueroa (1444-1461), Gómez Suárez de Figueroa (1479-1486) y Bernardino de Carvajal (1489-1493), obispos de Badajoz; y a los obispos de Plasencia Gonzalo Zúñiga (14151422), el cardenal Juan Carvajal (1446-1470) y Rodrigo Dávila (1470-1492). Ibíd., pp. 92-95.

${ }^{90}$ Ibíd., pp. 92-95. Para los obispos de Coria puede verse el trabajo de M. A. ORTí BELMOLTE, Episcopologio cauriense, Cáceres, 1959.

${ }^{91}$ Díaz CASSOU, Serie de los obispos de Cartagena, Madrid, 1895, pp. 62-63.
} 
En las sedes episcopales andaluzas la titularidad de la mitra también estará casi siempre en manos de importantes linajes nobiliarios, predominando la mediana o alta nobleza según la época y sede de que se trate. Así, por ejemplo, para el caso de Jaén, durante el siglo XIV casi todos los obispos procedieron de familias de la baja nobleza urbana castellana servidoras de la Monarquía, mientras que en la siguiente centuria encontraremos a obispos procedentes de linajes mucho más relevantes, tales como Gonzalo de Zúñiga (1422-1457), Alfonso Vázquez de Acuña (1457-1474), Iñigo Manrique de Lara (1475-1483) o Luis Osorio (1483-1496) .

En el obispado de Córdoba, durante los siglos XIV y XV será predominante la presencia de prelados cuya extracción social se situaba en la mediana nobleza cordobesa o andaluza ${ }^{93}$, aunque tampoco faltarán prelados procedentes de otros linajes. Este último es el caso de obispos como Alfonso de Vargas (1372-1379) o Juan Fernández Pantoja (1379-1397), de familias de caballeros toledanos ${ }^{94}$; Fray Alonso de Burgos (1477-1482), de la familia judeoconversa de los García de Santa María, de Burgos ${ }^{95}$; o Luis de Velasco (1484) e Iñigo Manrique de Lara (1485-1496), ambos de conspicuos linajes de la alta nobleza castellana ${ }^{96}$. Hay que poner de relieve, además, los vínculos familiares existentes entre algunos prelados. Así, el obispo Gutierre Ruiz de Mesa (1326-1336) era sobrino del anterior prelado cordobés Fernando de Mesa (1257-1274) ${ }^{97}$, y lo mismo puede decirse del obispo Martín Jiménez de Argote (1350-1362) con respecto a su tío Fernando Núñez Cabrera (1346-

\footnotetext{
${ }^{92} \mathrm{~J}$. RodríGuez Molina, El obispado de Baeza-Jaén, pp. 105-107.
}

${ }^{93} \mathrm{Se}$ trata sobre todo de familias cordobesas de hidalgos que ejercían un fuerte control sobre cargos concejiles y militares, o bien poseedoras de importantes señoríos en el obispado. Durante el siglo XIV los prelados procedentes de la mediana nobleza cordobesa o andaluza fueron los siguientes: Fernando Gutiérrez (1300-1326), de linaje cordobés; Gutierre Ruiz de Mesa (13261336), de una familia de caballeros; Juan Pérez Saavedra (1336-1346), de una familia de hidalgos cordobeses; Fernando Núñez Cabrera (1346-1350), de la casa Cabrera de Córdoba; Martín Jiménez de Argote (1350-1362); y Andrés Pérez Navarro (1363-1372), de una familia de la oligarquía sevillana. Iluminado SANZ SANCHO, Episcopologio medieval cordobés. Siglos XIII-XIV, pp. 40-59. En el siglo XV habrá cuatro obispos cuya extracción social se sitúa en la oligarquía urbana cordobesa: Fernando González Deza (1398-1426), Gonzalo Venegas (1426-1439), Sancho de Rojas (1440-1454) y Pedro de Córdoba y Solier (1464-1476). El obispo cordobés Fray Gonzalo de Illescas (1454-1464), en cambio, era de origen social humilde. I. SANZ SANCHO, Los obispos del siglo XV, "Hispania Sacra", 54 (2002), pp. 607 y ss.

${ }^{94}$ I. SANZ SANCHO, Episcopologio medieval cordobés. Siglos XIII-XIV, pp. 62-65.

${ }^{95}$ ÍDEM, Los obispos del siglo XV, p. 660.

${ }^{96}$ Ibid., pp. 667-668.

${ }^{97}$ ÍDEM, Episcopologio....Siglos XIII-XIV, p. 51. 
$1350)^{98}$, mientras que el mencionado Iñigo Manrique de Lara (1485-1496) era sobrino del homónimo arzobispo de Sevilla99.

Centrándonos ahora en la sede hispalense, entre 1303 y 1323 nos encontramos a don Fernando Gutiérrez Tello, sevillano y procedente de la pequeña nobleza local, ejerciendo la titularidad de la mitra, pero es sobre todo desde mediados del siglo XIV cuando será continua la presencia de prelados procedentes de grandes linajes nobiliarios como titulares de la mitra, junto a algunos de la mediana nobleza. Así, se sucederán arzobispos como Pedro Gómez Barroso de Albornoz (1369-1371); Fernando Álvarez de Albornoz (1371-1377); Pedro Álvarez de Albornoz (1378-1390); Alfonso de Egea (1403-1408); Diego de Anaya Maldonado (1418-1431; 1435-1437); Juan de Cerezuela y Luna (1433-1434), hermanastro de don Álvaro de Luna; Gutierre Álvarez de Toledo (1439-1442); García Enríquez Osorio (1442-1448); Juan de Cervantes (1449-1453); Alonso de Fonseca "el Viejo" (1454-1460; 14641473); Alonso de Fonseca "el Joven", sobrino del anterior (1460-1464); Pedro González de Mendoza, gran cardenal de España (1474-1482), que después pasaría a Toledo; Iñigo Manrique de Lara (1483-1485); Rodrigo de Borja (1484-1485), futuro papa Alejandro VI; y Diego Hurtado de Mendoza (1485-1502), sobrino del cardenal Pedro González de Mendoza ${ }^{100}$.

Por último, en lo que respecta a la diócesis de Cádiz, cuyas rentas eran bastante pobres, hay que poner de relieve el hecho de que durante la baja Edad Media la titularidad de la mitra la tendrán con mucha frecuencia obispos procedentes del clero regular, sobre todo de órdenes mendicantes, cuya extracción social, al menos durante el siglo XIV, será bastante modesta, mientras que durante el siglo XV habrá también algunos prelados absentistas al servicio de la Monarquía o del Papado ${ }^{101}$.

Finalmente, hay que destacar como algo frecuente el hecho de que muchos de estos prelados contasen en la curia episcopal con un séquito de familiares y servidores que se podría asimilar al que igualmente poseían algunos nobles, y así se ha demostrado para el caso de algunos obispos extremeños durante el siglo XV, pudiendo hablarse desde este punto de vista

${ }^{98}$ Ibid., p. 56

${ }^{99}$ ÍDEM, Los obispos del siglo XV, p. 668.

${ }^{100}$ Carlos Ros (dir.), Historia de la Iglesia de Sevilla, Barcelona, 1992, pp. 830-831.

${ }^{101} \mathrm{~J}$. SÁNCHEZ HERRERO, Episcopologio medieval gaditano, siglos XIII-XV, “En la España Medieval", 1 (1980), pp. 443-465.

«Anuario de Estudios Medievales», 35/2 (2005), pp. 557-603.- ISSN 0066-5061. 
de un cierto paralelismo entre nobleza laica y eclesiástica ${ }^{102}$. En ciertos casos podía suceder, incluso, que entre los familiares y amplias clientelas de algunos obispos se encontrasen algunos miembros de la baja nobleza, como hidalgos y caballeros, prestando apoyo militar al prelado, del mismo modo que también será muy frecuente que dentro de la amplia clientela de ciertos nobles haya algunos eclesiásticos sirviendo como capellanes.

\section{LOS CABILDOS CATEDRALICIOS ${ }^{103}$}

Dejando ya el Episcopado, la otra vía de acceso de algunos miembros de la nobleza a la alta jerarquía eclesiástica consistía principalmente en su incorporación a los cabildos catedralicios, que en sí mismos ya constituían dentro del ámbito urbano un resorte de poder esencial en las esferas social, económica e incluso política, por lo que muy pronto determinados linajes querrán intervenir en su control, y ello aparte de las teóricas posibilidades que el acceso previo al cabildo ofrecía para una futura promoción al Episcopado, si bien esto último muchas veces dependía más bien de las circunstancias coyunturales de cada diócesis y de la propia orientación de la política eclesiástica, dado que frecuentemente el paso previo por el cabildo catedralicio de una determinada sede episcopal no fue necesario para que un eclesiástico obtuviese, por mediación regia o pontificia, la titularidad de dicha sede.

Ya en el siglo XIII, o incluso antes, tenemos constancia de la presencia, todavía no muy fuerte en esta época, de miembros de las oligarquías urbanas en algunos cabildos catedralicios del ámbito castellano-leonés. Así, por ejemplo, durante esta centuria sabemos que determinadas familias compostelanas formaban parte tanto del cabildo catedralicio como del concejo, y dentro de aquél también había muchos miembros emparentados que

\footnotetext{
${ }^{102}$ José Luis MARTín MARTíN, op. cit., p. 88. La "corte episcopal” de algunos prelados extremeños del XV llegó a contar, entre familiares y servidores diversos, con más de cincuenta personas, número que sin duda aumentaba en el caso de las curias episcopales de otras mitras de mayor relieve, como Toledo, Sevilla o Santiago.

${ }^{103}$ Una reciente revisión historiográfica sobre los cabildos catedralicios castellanos en la Edad Media puede verse en $\mathrm{M}^{\mathrm{a}}$ José LOP OTíN, Las catedrales y los cabildos catedralicios de la corona de Castilla durante la Edad Media. Un balance historiográfico, "En la España Medieval", 26 (2003), pp. 371-404.
}

«Anuario de Estudios Medievales», 35/2 (2005), pp. 557-603.- ISSN 0066-5061. 
ocupaban determinados cargos ${ }^{104}$. Por otro lado, en Burgos algunas familias de mercaderes-caballeros no sólo controlarán el concejo, sino que también tendrán una importante presencia en el cabildo catedralicio; de este modo, el cargo de deán y algunas canonjías y arciprestazgos los ocuparán a menudo miembros de dos importantes familias de la ciudad como eran los Sarracín y los Bonifaz ${ }^{105}$.

Pero fue sobre todo en los siglos XIV y XV cuando se convirtió en más frecuente la incorporación a los cabildos catedralicios de eclesiásticos procedentes de linajes de los diversos niveles nobiliarios, cosa que, por otro lado, también se observa en los cabildos de otros reinos peninsulares ${ }^{106}$. A lo largo de estas dos centurias, y fundamentalmente en la última, se consolidará en el reino de Castilla la mediana y baja nobleza de hidalgos y caballeros, grupo muy abundante y nervio principal del estamento nobiliario debido a su movilidad y relativa apertura, quizá no tan acusada como en tiempos anteriores, pero aún patente, dado que permanecía la capacidad regia para crear hidalgos, siendo también frecuentes los "caballeros de privilegio" creados por el rey y los "caballeros de cuantía", que abrían a muchos descendientes de villanos el acceso a la baja nobleza al cabo de tres generaciones. Los monarcas otorgarán muchas hidalguías y caballerías a quienes les prestaron ayuda en diferentes guerras, desde fines del XIV hasta 1492, y sólo desde este último año las mercedes regias disminuyeron. Los miembros más poderosos de estos grupos fueron el núcleo principal de una mediana nobleza que se constituyó en la oligarquía urbana que ejercerá el control de los

\footnotetext{
${ }^{104}$ Así, por ejemplo, miembros de la familia Abril solían ser tesoreros, mientras que en la familia Pichoth predominaban los arcedianos y chantres. M. GONZÁLEZ VÁZQUEZ, F.J. PÉREZ RODRÍGUEZ, op. cit., pp. 1091-1098.

${ }^{105} \mathrm{~T}$. RuIz, Burgos y el comercio castellano en la baja Edad Media. Economía y mentalidad, "La ciudad de Burgos (Actas del Congreso de Historia de Burgos)", Madrid, 1985, p. 53. Sobre estos linajes puede verse el trabajo, del mismo autor, Los Sarracin y los Bonifaz. Dos linajes patricios de Burgos, 1248-1350, "Sociedad y poder real en Castilla", Barcelona, 1981, pp. 121144.

${ }^{106}$ En el cabildo catedralicio de Pamplona, por ejemplo, durante el siglo XIV muchos canónigos fueron segundones de familias de ricoshombres navarros como los Asiáin, Aibar, Medrano, Eusa y Olloqui, que a veces se perpetuarán en los cargos formando dinastías canonicales. También hubo representantes de algunas familias de caballeros navarros, así como algunos miembros de la ascendente burguesía, como los Folcaut o los Zalba, que querían equipararse a la nobleza hereditaria. Finalmente, hubo asimismo integrantes del cabildo que eran de baja extracción social. En todo caso, la mayoría de los canónigos fueron de procedencia navarra, aunque también habrá algunos originarios de Francia, Aragón o Castilla. Francisco Javier JIMÉNEZ GUTIÉRREZ, El cabildo pamplonés en el siglo XIV. Un análisis prosopográfico, "Príncipe de Viana", 53 (1992), pp. 391-408.
} 
gobiernos municipales de las ciudades durante el siglo $\mathrm{XV}^{107}$, y muchos de cuyos integrantes accederán también a los cabildos catedralicios.

Esta progresiva incorporación de miembros de determinadas familias a los puestos capitulares les posibilitaba ejercer un cierto grado de influencia sobre los cabildos catedralicios, que constituían verdaderos aparatos de poder dentro del sistema político urbano que no debían quedar fuera de su control, siendo ello, dentro de un amplio marco de relaciones de poder, un complemento esencial al control que, aún en mayor medida, llegarían a ejercer algunas de estas familias sobre los concejos, y más ocasionalmente sobre otras instituciones eclesiásticas, tales como monasterios, colegiatas o iglesias de patronato. Veamos a continuación diferentes ejemplos sobre la integración de algunos linajes nobiliarios y oligarquías urbanas en los cabildos catedralicios.

Comenzando por Santiago de Compostela, hay que señalar que durante las dos últimas centurias de la Edad Media, continuando con la tendencia que ya se observaba en el siglo XIII, ciertas familias de la oligarquía de la ciudad estarán también presentes en el cabildo catedralicio, y así se observa en linajes como los Tudela, Fructuoso o Eanes, todo ello al margen de que algunos arzobispos hubieran pertenecido previamente al cabildo compostelano ${ }^{108}$. Por otro lado, durante el siglo XV el linaje Fonseca estará también presente en el cabildo gracias al apoyo de los prelados de esta familia que ostentaron la titularidad de la mitra. Así, por ejemplo, a fines de esta centuria se incorporarán al cabildo un buen número de personajes que eran familiares o allegados del arzobispo Alonso de Fonseca II, buena parte de los cuales formarán el equipo de gobierno de su hijo y sucesor ${ }^{109}$.

En el cabildo catedralicio de Lugo, muy presionado económica y jurisdiccionalmente por la nobleza gallega, sabemos que también hubo

\footnotetext{
${ }^{107}$ Los hidalgos fueron muy abundantes sobre todo en las montañas del norte, pero no en Galicia. En las regiones del centro el número de hidalgos fue algo menor, dado que allí vivían la mayor parte de los grandes linajes. Finalmente, en Andalucía y Murcia había pocos hidalgos, pero sí abundantes caballeros que controlaban el poder municipal. Miguel Ángel LADERO QUESADA, Los señores de Andalucía. Investigaciones sobre nobles y señorios en los siglos XIII al $X V$, pp. 21-23.

${ }^{108}$ F.J. PÉREZ RODRÍGUEZ, El dominio del cabildo catedral de Santiago de Compostela en la Edad Media, siglos XII-XIV, Santiago de Compostela, 1994, p. 13.

${ }^{109}$ M. VÁZQUEZ BERTOMEU, El arzobispo don Alonso II de Fonseca. Notas para su estudio, "Cuadernos de Estudios Gallegos", 47 (2000), p. 108.

«Anuario de Estudios Medievales», 35/2 (2005), pp. 557-603.- ISSN 0066-5061.
} 
vinculación de los canónigos con algunas de las principales familias de hidalgos de la ciudad, que nutrirán buena parte del cabildo ${ }^{110}$.

Centrándonos a continuación en la diócesis de León, hay que poner de relieve la integración en el cabildo catedralicio a comienzos del siglo XV de algunos segundones de linajes como los Quiñones, Osorio, Guzmán, Enríquez o Acuña, que además actuarán frecuentemente como arrendatarios de bienes y rentas capitulares. Por ejemplo, durante el periodo 1419-1426 Lope Núñez de Guzmán era canónigo, Alvar Pérez Osorio deán y Rodrigo Enríquez arcediano de Valdemeriel ${ }^{111}$. A fines de siglo algunas regidurías del concejo leonés estaban ocupadas por Quiñones, Guzmanes y Acuña, cuyos miembros seguirán teniendo alguna representación en el cabildo ${ }^{112}$. Por otro lado, también durante el siglo XV, familias de la oligarquía urbana leonesa como los Villafañe, Cabeza de Vaca, Villamizar o Ferrández de León, todos ellos de la baja nobleza y dentro del círculo de influencia de grandes linajes como Quiñones o Guzmanes, estarán presentes tanto en el cabildo catedralicio como en el concejo ${ }^{113}$.

En Palencia, sobre todo en el siglo XV, el señorío ejercido por el obispo y cabildo, al suplantar en cierto modo la posición de la nobleza en otras ciudades, facilitaría una mayor libertad de acción a la burguesía, tanto para su promoción a la condición de caballeros e hidalgos como para su acceso al gobierno municipal y cabildo catedralicio. El caso más significativo son las familias Rúa y Villoldo, que se presentan como caballeros e hidalgos con sólido poder económico, pero con origen burgués por su dedicación al comercio de paños e industria textil de la ciudad. Ambas familias, emparentadas entre sí y vinculadas al concejo, también se integraron en el cabildo a través de algunos de los descendientes varones del linaje, lo que a su vez les vinculaba al obispo, que era quien, como señor de la ciudad, nombraba a los regidores y alcaldes concejiles. En este caso, pues, la interconexión concejocabildo catedralicio no puede ser más explícita. Por otro lado, al integrarse en

${ }^{110} \mathrm{M}^{\mathrm{a}}$ José Portela Silva; José García ORo, La Iglesia y la ciudad de Lugo en la baja Edad Media. Los señoríos. Las instituciones. Los hombres, Santiago de Compostela, 1997, pp. 221-256.

${ }^{111} \mathrm{M}^{\text {a }}$ Isabel Nicolás CRISPíN; M. BAUTISTA BAUTISTA, La organización del cabildo catedralicio leonés a comienzos del siglo XV (1419-1426), León, 1990, pp. 315-316.

${ }^{112}$ J.M ${ }^{\text {a }}$ SANTAMARTA LuENGOS, Señorio y relaciones de poder en León en la baja Edad Media. Concejo y cabildo catedral en el siglo XV, León, 1993, p. 34.

${ }^{113}$ Ibíd., pp. 84-93.

«Anuario de Estudios Medievales», 35/2 (2005), pp. 557-603.- ISSN 0066-5061. 
el cabildo, podían también vincular rentas eclesiásticas a capellanías de su familia, a la vez que las exequias fúnebres por los canónigos miembros del linaje contribuían a realzar el prestigio de este último, algo muy conveniente desde un punto de vista propagandístico sobre todo para los Rúa, dado su origen judeoconverso ${ }^{114}$. Al margen de la presencia de ambas familias, en el cabildo catedralicio de Palencia también nos encontraremos con algunos representantes de importantes linajes nobiliarios, como por ejemplo Esteban Fernández, sobrino del obispo palentino don Gutierre Gómez, que en 1375 era maestrescuela ${ }^{115}$.

Respecto a la presencia nobiliaria en el cabildo catedralicio de Calahorra, puede señalarse que en la primera mitad del siglo XIV el cargo de arcediano de Álava aparece en manos de Fernán Ruiz de Gaona, uno de los terratenientes más poderosos de la región. Por otra parte, ya para la segunda mitad del XV, algunos documentos citan como arcediano de Berberigo a Diego Hurtado de Mendoza, miembro de la rama alavesa del linaje de los Mendoza ${ }^{116}$.

En algunos cabildos catedralicios de diócesis modestas lo que caracteriza a sus miembros es su diversificada y por lo general no muy elevada extracción social. Así sucederá, por ejemplo, en El Burgo de Osma durante el siglo $\mathrm{XV}$, en cuyo cabildo la impronta nobiliaria no fue muy intensa y apenas hubo representantes de la alta nobleza, sino más bien miembros de clases medias urbanas, locales y foráneas, donde coexistían hidalgos y pecheros. Hay que destacar también la presencia en este cabildo de algunos clérigos originarios de familias judeoconversas sorianas como los San Clemente o los Beltranes ${ }^{117}$.

En Burgos, al menos durante la primera mitad del siglo XIV, algunas familias de mercaderes-caballeros como los Sarracín y los Bonifaz seguirán estando presentes tanto en el gobierno municipal como en el cabildo

\footnotetext{
${ }^{114} \mathrm{M}^{\mathrm{a}}$ A. ESTEBAN RECIO; $\mathrm{M}^{\mathrm{a}} \mathrm{J}$. IZQUIERDO GARCÍA, Familias burguesas representativas de la élite palentina a fines de la Edad Media, "Studia Historica. Historia Medieval", 10 (1992), pp. 108-109.

${ }^{115}$ F.J. FERNÁNDEZ CONDE, Gutierre de Toledo, obispo de Oviedo, p. 35.

${ }^{116} \mathrm{~J}$. L.MANERO LEÓN, Relaciones entre la diócesis de Calahorra y el País Vasco a fines de la Edad Media y comienzos de la Moderna según la documentación conservada en el Archivo Catedralicio calagurritano, "El pueblo vasco en el Renacimiento, 1491-1521", Bilbao, 1994, pp. 517-518.

${ }^{117}$ Vid. Máximo DIAGo HERNANDO, Notas sobre el origen social del clero capitular de El Burgo de Osma y Soria en los siglos XV y XVI, "I Semana de Estudios Históricos de la diócesis de Osma-Soria. 15-17 de septiembre de 1997", Soria, 2000, I, pp. 37-63, en especial pp. 39-45.

«Anuario de Estudios Medievales», 35/2 (2005), pp. 557-603.- ISSN 0066-5061.
} 
catedralicio, tal como ya venía sucediendo desde fines del siglo XIII, según se dijo páginas atrás ${ }^{118}$. Ya durante el siglo $\mathrm{XV}$, en ocasiones encontramos a algunos miembros de la familia Alonso de Burgos-Maluenda, emparentada con los García de Santa María, ocupando algunas canonjías y dignidades en el cabildo burgalés; se trataba de una familia de comerciantes cuyos integrantes también tenían cargos en el concejo ${ }^{119}$. Por otro lado, los dos obispos del linaje judeconverso García de Santa María, don Pablo y don Alonso, ejercieron durante la primera mitad de siglo un fuerte control sobre los beneficios del cabildo catedralicio, concediendo prebendas a algunos de sus parientes, según se verá más adelante. Pero, además, también encontraremos a miembros de otros importantes linajes de la nobleza castellana ostentando beneficios en el cabildo burgalés. En este sentido podrían señalarse, a modo de ejemplo, las concesiones beneficiales realizadas a instancias del obispo don Alonso de Cartagena (1435-1456) a favor de familiares de don Álvaro de Luna, el conde de Haro y el marqués de Santillana. En ellas habría que ver, por un lado, un agradecimiento al condestable por el apoyo prestado a don Alonso para su promoción al Episcopado, y, por otra parte, un resultado de las estrechas relaciones que el obispo mantuvo con los mencionados conde y marqués durante las turbulencias políticas de mediados del siglo XV. Quien también acumuló muchos beneficios en Burgos fue Rodrigo Sánchez de Arévalo, compañero de don Alonso en labores diplomáticas, que obtuvo una canonjía, fue designado capellán real, y en 1440 recibió el arcedianato de Treviño, uno de los más valiosos de la diócesis ${ }^{120}$. A todo este fuerte control ejercido sobre el cabildo por los obispos del linaje García de Santa María (o Cartagena) habría que sumar el hecho de que el linaje también tenía una importante presencia en el concejo burgalés, lo que reforzaba aún más su posición a la cabeza de la oligarquía urbana. Pero la llegada a Burgos del obispo don Luis de Acuña

\footnotetext{
${ }^{118}$ T. RuIz, Burgos y el comercio castellano, p. 53.

${ }^{119} \mathrm{H}$. CASADO AlONSO, Una familia de la oligarquía burgalesa del siglo XV: los Alonso de Burgos-Maluenda, "La ciudad de Burgos (Actas del Congreso de Historia de Burgos)", Madrid, 1985 , p. 158.

${ }^{120}$ En 1437, mientras el obispo don Alonso se encontraba en Basilea y su hermano se ocupaba de las funciones episcopales, se le concedió a Juan de Luna, hijo del condestable, la canonjía y préstamos en el cabildo catedralicio burgalés de que gozaba don Alonso antes de ser obispo. Ese mismo año también se ordenó la entrega de varios préstamos en la diócesis a otro hijo del favorito, Pedro de Luna. Por otro lado, varios familiares del conde de Haro y del marqués de Santillana también obtuvieron prebendas en el cabildo. L. FERNÁNDEZ GALLARDO, Alonso de Cartagena (1385-1456), pp. 252-253.
} 
(1456-1495), acompañado por toda sus corte de familiares, rompería el equilibrio anterior capitaneado por los Cartagena, y se producirían multitud de conflictos entre cabildo y concejo por el control del poder en la ciudad ${ }^{121}$.

En Segovia conseguirían ingresar en la institución capitular algunos miembros de importantes familias de mercaderes de la ciudad como los Segovia, Castro o Cuellar, si bien durante el siglo XV fueron los Arias Dávila, linaje converso, quienes, por mediación del obispo del linaje don Juan Arias, consiguieron introducir en el cabildo a un mayor número de miembros de la familia o de otros linajes afines ${ }^{122}$.

Por lo que respecta al cabildo catedralicio conquense, resulta relevante el control que sobre las dignidades capitulares ejercieron algunos poderosos linajes bien asentados en el obispado, como los Albornoz, durante el siglo XIV, o los Carrillo y Mendoza, durante la siguiente centuria. El propio Gil Álvarez de Albornoz, nacido en Cuenca hacia 1302, era ya canónigo y arcediano de Huete en 1325, y en los dos años siguientes tendrían lugar sendos intentos del cabildo catedralicio conquense de elegirle, a pesar de su juventud, como obispo de la diócesis, siendo en ambos casos anulada la elección por el papa, lo que no impediría que años más tarde llegase a ser arzobispo de Toledo y cardenal. Por otro lado, las familias de hidalgos de la oligarquía urbana, que tenían una destacada presencia en el concejo conquense, consiguieron acceder sobre todo a raciones y canonjías en el cabildo, pero raras veces a dignidades ${ }^{123}$.

En Toledo, el prestigio que le daba su categoría de sede primada contribuirá a que en el cabildo catedralicio sean muy numerosos los eclesiásticos de extracción nobiliaria. Así, durante el siglo XV estarán presentes, con mayor o menor amplitud, todos los grupos importantes de la oligarquía urbana. Por un lado, los Ayala y los Silva, linajes rivales que se habían

${ }^{121} \mathrm{H}$. CASAdo Alonso, La propiedad eclesiástica en la ciudad de Burgos en el siglo XV: el cabildo catedralicio, Valladolid, 1980, p. 146.

${ }^{122}$ Miguel SANTAMARÍA, El cabildo catedralicio de Segovia como aparato de poder en el sistema político urbano durante el siglo XV, "Studia Historica. Historia Medieval", 8 (1990), pp. 60-67.

${ }^{123}$ Una visión detallada sobre la extracción social de los miembros del cabildo catedralicio conquense puede verse en mi trabajo Las relaciones Iglesia-Nobleza en el obispado de Cuenca, pp. 299-306. Ejemplos de familias conquenses de hidalgos con presencia en el concejo y cabildo son, entre otras, los Cañizares, Chirino, Cañaveras, Molina o Torralba. Por otro lado durante el siglo XV los Mendoza también tuvieron importantes cargos concejiles en Cuenca, sobre todo el de guarda mayor. Sobre ello puede verse J.A. JARA FUENTES, La nobilización de un concejo en el siglo XV: Cuenca y los Hurtado de Mendoza, "La Península Ibérica en la era de los Descubrimientos: 1391-1492", Sevilla, 1997, II, pp. 1025-1034.

«Anuario de Estudios Medievales», 35/2 (2005), pp. 557-603.- ISSN 0066-5061. 
asentado en tierras toledanas con los Trastámara. Por otra parte encontramos en el cabildo a linajes de caballeros originarios de Toledo como los Niño, Cervatos, Palomeque, Pantoja o Ribera. Asimismo, también habrá clérigos cuya extracción social se situaba en familias de una oligarquía toledana algo inferior, pero con peso económico, como los Illescas, Villarreal, Ortiz y Zapata, estos dos últimos de origen judeoconverso. Muchos canónigos de las familias citadas, siguiendo los intereses de su linaje, tomarían parte a favor de uno $u$ otro bando en las luchas de bandos que se produjeron en la ciudad durante el siglo XV, llegando incluso algunos de ellos a ser expulsados de la ciudad. Finalmente, no faltaron por supuesto en el cabildo toledano clérigos miembros de los más importantes linajes de la gran nobleza señorial, como los Mendoza, Carrillo de Albornoz, Guzmán, Luna o Álvarez de Toledo, entre otros ${ }^{124}$. Especialmente elocuente resulta la nómina de miembros del cabildo en época del cardenal Cisneros (1495-1517), donde figura una amplia representación de personajes procedentes de los más grandes linajes de la alta y mediana nobleza castellana ${ }^{125}$, linajes que por lo general, salvo algunas excepciones, seguirán estando presentes en el cabildo toledano hasta bien entrada la Edad Moderna ${ }^{126}$.

Respecto al cabildo catedralicio murciano, hay que señalar que la perpetuación de linajes locales en el mismo fue difícil y estuvo muchas veces

${ }^{124} \mathrm{M}^{\text {a }}$ J. Lop OTín, El cabildo catedralicio de Toledo en el siglo XV, Madrid, 2003, pp. 425426. Para la primera mitad del siglo XV algunos ejemplos que pueden citarse son los de Juan Fernández de Luna, canónigo en 1410; y Juan de Luna, arcediano de Talavera en 1437 por súplica regia, pese a tener tan sólo 15 años de edad. Por otro lado, el cargo de Adelantado de Cazorla, que solía ostentarlo un laico, era ejercido por Juan Carrillo en 1445. O. VILLARROEL GONZÁLEZ, Las relaciones entre la Monarquía y el arzobispado de Toledo en época de Juan II de Castilla (1406-1454), Toledo, 2002, pp. 257-261.

${ }^{125}$ Figuran, entre otros, nombres como Juan de Cabrera (arcediano de Toledo); Luis Hurtado (abad de Santa Leocadia); Pérez de Montemayor (canónigo obrero); Fernando de Fonseca (canónigo); Francisco Alvarez de Toledo (maestrescuela); Vasco de Guzmán (abad de San Vicente); Bernardino de Mendoza (arcediano de Guadalajara); Alonso de Albornoz (capellán mayor); Rodrigo Tenorio (canónigo); Pedro Martínez de Ayala (canónigo); así como varios canónigos de la familia Ortiz. José GARCíA ORO, La Iglesia de Toledo en tiempo del cardenal Cisneros (1495-1517), Toledo, 1992, pp. 74-75. Durante el siglo XVII seguirá siendo habitual esta presencia nobiliaria en el cabildo toledano, sobre todo con segundones de linajes privilegiados como los Guzmán, Sandoval o Zúñiga, entre otros. A este respecto puede verse: Ramón SÁNCHEZ GoNZÁleZ, Iglesia y sociedad en la Castilla Moderna. El cabildo catedralicio de la sede primada. Siglo XVII, Cuenca, 2000, pp. 128 y ss.

${ }^{126} \mathrm{~A}$ lo largo del siglo XVI hubo en el cabildo catedralicio toledano numerosos miembros del linaje Mendoza, que fue el que tuvo más peso y acaparó más dignidades, así como también muchos miembros de los linajes Ayala, Zapata, Sandoval, Pacheco, Guzmán, Manrique, Lara, Suárez y Ortiz, entre otros, además de varios sobrinos del cardenal Quiroga. Vid. A. FERNÁNDEZ COLLADO, Grupos de poder en el cabildo toledano del siglo XVI, "Sociedad y élites eclesiásticas en la España Moderna" (coord. F.J. ARANDA PÉREZ), Cuenca, 2000, pp. 149-162.

«Anuario de Estudios Medievales», 35/2 (2005), pp. 557-603.- ISSN 0066-5061. 
impedida por la continua acción episcopal y la llegada de beneficiados foráneos, por lo que habrá que esperar a la segunda mitad del siglo XV para documentar un verdadero control de la oligarquía local sobre las prebendas. Con todo, algunas familias de hidalgos murcianos mantuvieron de forma continua su presencia en el cabildo desde el siglo XIV, como por ejemplo los Pedriñán, los Porcel y los Riquelme, sustituidos a mediados del XV por otros linajes locales como los Selva, Onteniente, Montealegre y Pérez de Valladolid, linajes todos ellos muy vinculados a los poderes políticos regionales y a la burocracia regia ${ }^{127}$. En cuanto a la presencia de linajes foráneos en el cabildo murciano, conviene destacar que sería frecuente durante los siglos XIV y XV, siendo casi siempre los obispos quienes sirvieron de soporte para la expansión de estos linajes en el reino de Murcia ${ }^{128}$. La alianza entre la alta jerarquía eclesiástica murciana y la oligarquía urbana no sólo se realizó mediante el ingreso de hidalgos en el cabildo catedralicio, sino que también se establecieron lazos de vasallaje entre la baja nobleza y el alto clero murciano. De este modo, obispos y miembros del cabildo catedralicio mantuvieron pequeños grupos de caballeros y escuderos que se convirtieron en sus séquitos militares en épocas de alteración política, y de hecho las constituciones sinodales murcianas intentan garantizar la fidelidad de estos séquitos. Además, el obispo tenía vínculos vasalláticos con algunos linajes urbanos, dado que todos, en definitiva, formaban la oligarquía dirigente ${ }^{129}$.

Centrándonos por último en las diócesis andaluzas, comenzaremos señalando que en el cabildo catedralicio cordobés fue habitual que buena parte de los canónigos y, sobre todo, las dignidades procediesen de algunas de las más importantes familias de hidalgos que conformaban la oligarquía urbana

${ }^{127}$ I. GARCíA DÍAZ; M. RoDRíGUEZ LLOPIS, Iglesia y sociedad feudal: el cabildo de la catedral de Murcia, pp. 68-72.

${ }^{128}$ Las familias Magaz, Peñaranda, Puxmarín, Pedrosa, Comontes y Oña eran foráneas, y se establecieron en Murcia formando linajes ligados a instituciones locales, que consolidarán su presencia gracias al apoyo episcopal. Así, por ejemplo, don Diego Martínez de Magaz fue obispo de Cartagena en 1278, don Pedro de Peñaranda entre 1330 y 1349, y don Diego de Comontes entre 1447 y 1458 . Parientes de estos obispos se perpetuarían en cargos capitulares y concejiles. Otras familias, como los Puxmarín y los Oña, se asentaron en Murcia a fines del XIV gracias a la obtención de una dignidad capitular por alguno de sus miembros. I. GARCía DíAZ, M. RODRÍGUEZ LLOPIS, op. cit., pp. 64-68.

${ }^{129}$ Ibid., p. 51.

«Anuario de Estudios Medievales», 35/2 (2005), pp. 557-603.- ISSN 0066-5061. 
cordobesa, familias que también ejercían un fuerte control en el concejo y frecuentemente prestaban servicios a la Realeza ${ }^{130}$.

En el cabildo catedralicio hispalense, donde una canonjía equivalía socialmente a la posesión de una veinticuatría en el concejo, se llegarían a crear pequeñas dinastías de canónigos salidas de linajes como los Cervantes, Córdoba o Fuentes, entre otros, siendo habitual la carrera eclesiástica sobre todo entre los segundones y célibes de los linajes nobiliarios, que se incorporaron fundamentalmente a puestos medios y altos de la Iglesia. Ello, entre otras cosas, ayudaba a regular los excedentes generacionales y aportaba beneficios económicos al linaje en cuestión ${ }^{131}$. Los Córdoba, por ejemplo, aparecen en el cabildo sevillano a lo largo de diversos momentos durante la baja Edad Media; así, entre varios casos que se pueden citar, tenemos a Domingo Pérez de Córdoba como racionero en 1275, a Esteban Pérez de Córdoba como canónigo en 1309 y a Gonzalo Sánchez de Córdoba como arcediano de Jerez en $1467^{132}$. Otros miembros de importantes linajes formaban parte del cabildo sevillano. En 1442, por ejemplo, Pedro Bocanegra era maestrescuela, y como canónigos figuran Alfonso González de Orbaneja y Pedro Afán de Ribera ${ }^{133}$. Finalmente, hay que destacar que algunas de las principales familias del grupo caballeresco de Sevilla también nutrirían al cabildo catedralicio ${ }^{134}$, tal como sucedió con los Marmolejo. Así, en 1486, Nicolás Martínez Marmolejo era canónigo y arcediano de Sevilla, y su hermano Diego Fernández Marmolejo arcediano de Écija ${ }^{135}$.

Dentro de las relaciones clientelares que se daban en los cabildos catedralicios pueden distinguirse varios niveles. Por un lado, nos encontramos con los clérigos y capellanes reales, muchos de ellos procedentes de la nobleza

${ }^{130}$ I. SANZ SANCHO, La Iglesia y el obispado de Córdoba en la baja Edad Media (1236-1426), Madrid, 1989, I, pp. 695-698.

${ }^{131}$ Durante el siglo XIV un $66 \%$ de los célibes, hombres y mujeres, de la nobleza sevillana tomó la carrera eclesiástica, cifra que se reducirá a un $42 \%$ en la centuria siguiente. Rafael SÁNCHEZ SAUS, Caballería y linaje en la Sevilla medieval, Cádiz, 1989, pp. 75-76.

${ }^{132}$ J. SÁNCHEZ HERRERO, Sevilla medieval, en "Historia de la Iglesia de Sevilla" (Dir. Carlos ROS), Sevilla, 1992, p. 142.

${ }^{133}$ Archivo Catedralicio de Sevilla, sección IX, caj. 180, $\mathrm{n}^{\circ} 23$.

${ }^{134}$ Entre las principales familias de caballeros de Sevilla en el siglo XV cabe destacar a los Marmolejo, Barba, Cerón, Esquivel, Medina, Ortiz, Tous, Fuente y Melgarejo. M.A. LADERO QUESADA, Los señores de Andalucia, p. 61.

${ }^{135}$ Archivo Catedralicio de Sevilla, sección IX, caj. 114, no 36 (testamento de Nicolás Martínez Marmolejo).

«Anuario de Estudios Medievales», 35/2 (2005), pp. 557-603.- ISSN 0066-5061. 
local. Muy frecuente fue también la presencia de eclesiásticos que formaban parte del amplio círculo de familiares de algún cardenal; uno de los varios ejemplos que podrían citarse sobre el particular es el del cardenal don Gil de Albornoz, quien entre 1351 y 1367 ejerció un enorme control sobre gran cantidad de beneficios de los cabildos catedralicios castellanos, que el papa otorgaría por mediación suya a sus familiares y protegidos.

Especialmente significativa será, por otro lado, la presencia en los cabildos de clérigos que formaban parte del círculo de parientes y familiares del obispo diocesano o de algunas dignidades capitulares influyentes; ello permitiría, sobre todo en los siglos XIV y XV, que se formasen auténticas dinastías eclesiásticas diocesanas, siendo frecuentes los vínculos familiares tíosobrino o incluso padre-hijo, situación esta última en la cual se hacía imprescindible la búsqueda de las necesarias fórmulas de legitimación. A continuación señalaremos tan sólo algunos ejemplos al respecto, de entre los muchos que podrían citarse.

Para la archidiócesis compostelana hay que recordar, según dijimos páginas atrás, la llegada masiva al cabildo catedralicio de personajes cercanos al arzobispo Alonso de Fonseca II que se produjo a fines del siglo XV. Este prelado, entre otras concesiones, otorgó a uno de sus dos hijos, llamado también Alonso, una canonjía en el cabildo compostelano en 1490 , y el arcedianato de Cornado en 1496. También por mediación paterna obtendría en 1492 otro beneficio en la iglesia de Córdoba, regida desde 1499 por su pariente Juan Rodríguez de Fonseca ${ }^{136}$. Por otra parte, Pedro de Mendoza, nepote del arzobispo de Santiago Lope de Mendoza, obtuvo una canonjía en el cabildo compostelano por mediación de Enrique III $^{137}$, mientras que en Sevilla arzobispos como Juan de Cervantes y Diego de Anaya, entre otros, introdujeron a primos y sobrinos en el cabildo, además de casar a algunas de sus sobrinas con nobles sevillanos ${ }^{138}$.

En el obispado de Oviedo, durante la segunda mitad del siglo XIV nos encontramos como beneficiados en el cabildo catedralicio a algunos parientes del obispo ovetense don Gutierre Gómez de Toledo. Así, por ejemplo, su

\footnotetext{
${ }^{136}$ M. VÁzQuez Bertomeu, El arzobispo don Alonso II de Fonseca, p. 108.

${ }^{137}$ J.M. NIETO SORIA, Iglesia y génesis, p. 449.

${ }^{138} \mathrm{R}$. SÁNCHEZ SAUS, Caballería y linaje en la Sevilla medieval, p. 76. En el testamento de cardenal y arzobispo sevillano Juan de Cervantes, dado el 16 de noviembre de 1453 , se dejan ciertos bienes a su sobrino homónimo Juan, arcediano de Sevilla e hijo de una hermana suya. Archivo Catedralicio de Sevilla, secc. IX, caj. 107, $\mathrm{n}^{\circ} 17 / 2$, f. 3v.

«Anuario de Estudios Medievales», 35/2 (2005), pp. 557-603.- ISSN 0066-5061.
} 
hermano Esteban Fernández fue canónigo y arcediano de Babia, y parece que hacia 1384 era ya deán, mientras que dos sobrinos del obispo don Gutierre, García Yuste y Sugerio Téllez, ocuparían también sendas canonjías durante el pontificado de su tío ${ }^{139}$.

En la diócesis de Ávila, tal como ya dijimos con anterioridad, gracias a la titularidad de la mitra que ostentó durante más de cuarenta años, el obispo don Sancho Blázquez (1312-1355), del linaje abulense de los Dávila, consiguió introducir en el cabildo a algunos de sus parientes, siendo ejemplo de ello sus sobrinos-nietos el maestre Sancho Sánchez, canónigo y arcediano de Olmedo, y el igualmente canónigo Fernán Blázquez. El primero de ellos tuvo el cargo de arcediano de Olmedo desde 1338, y lo seguía ostentando en 1363; consiguió formar un importante patrimonio mediante numerosas compras, y en su testamento repartiría estos bienes entre el cabildo abulense, otras instituciones religiosas y algunos de sus familiares, dejando a estos últimos bienes en usufructo vitalicio que luego pasarían al cabildo. Una prueba de la importancia que para el linaje de los Dávila tuvo esta proyección dentro del estamento eclesiástico la constituye el hecho de que frecuentemente los miembros principales del linaje obligaron a alguno de sus hijos a ser clérigo para poder heredar ${ }^{140}$.

También en el cabildo catedralicio de Plasencia contamos con ejemplos parecidos. Así, durante el pontificado del obispo Pedro (1375-1401), aparecen tres sobrinos suyos como arcedianos y canónigos, y en época del obispo y cardenal Juan de Carvajal (1446-1470) fueron arcedianos de Plasencia Rodrigo de Carvajal y luego Sancho de Carvajal, mientras que Álvaro de Carvajal figura como arcediano de Trujillo ${ }^{141}$.

En el cabildo burgalés, durante la primera mitad del siglo XV se dejará sentir la influencia de los obispos del linaje García de Santa María (o Cartagena), por cuya mediación algunos de sus parientes obtendrán beneficios. Así, por ejemplo, el ya citado obispo de Oviedo y Calahorra Juan Díaz

${ }^{139}$ F.J. FERNÁNDEZ CONDE, Gutierre de Toledo, obispo de Oviedo, pp. 35-37. El obispo de Oviedo don Gutierre, siguiendo una política encaminada a reforzar el linaje de los Toledo, consiguió que su hermana María Gómez se casase con el magnate astur Lope González de Quirós, entroncando así con la nobleza asturiana.

${ }^{140}$ J.I. MORENO NÚÑEZ, Poder económico e influencia social de un clérigo castellano del siglo XIV: Sancho Sánchez, arcediano de Olmedo, pp. 398-399. Desde fines del siglo XIII ya contamos con ejemplos del miembros del linaje Dávila que accedieron al cabildo catedralicio: tal es el caso de Velasco Velázquez, arcediano de Ávila (1297-1303) y deán (1303-1307). Ibíd., p. 398.

${ }^{141}$ J.L. MARTín MARTín, Los obispos de Extremadura en la Edad Media, p. 76.

«Anuario de Estudios Medievales», 35/2 (2005), pp. 557-603.- ISSN 0066-5061. 
de Coca, sobrino del obispo burgalés don Pablo de Santa María, fue racionero de Burgos y desde 1428 canónigo y abad de Cervatos, llegando a deán en $1458^{142}$. Por otro lado Pablo de Cartagena, nieto del obispo don Pablo, obtuvo de éste en 1433 media ración, y en 1440 ya era canónigo ${ }^{143}$, mientras que Alfonso Rodríguez Maluenda, otro sobrino de don Pablo, era en 1424 canónigo de Burgos ${ }^{144}$. En 1431 Juan Garcés Maluenda, hermano del anterior, obtuvo media ración, y en 1454 figura como canónigo burgalés, al igual que Juan Ortega Maluenda, otro pariente del linaje ${ }^{145}$, mientras que Luis de Maluenda fue desde 1466 racionero y posteriormente tesorero de Burgos ${ }^{146}$. Asimismo sabemos que Sancho de Prestines, arcediano de Lara, tenía algún vínculo de parentesco con don Alonso de Cartagena ${ }^{147}$, quien en 1447 intercedería también ante el papa para que su sobrino Juan de Burgos consiguiese una canonjía en Calahorra ${ }^{148}$. Años más tarde, en cambio, con la llegada a Burgos del obispo Luis de Acuña y Osorio, serán los familiares de éste quienes tengan una mayor presencia en el cabildo, y así, por ejemplo, en 1475 aparecen como canónigos Martín Vázquez de Acuña, Cristóbal Osorio y Juan Osorio, todos ellos parientes del obispo burgalés ${ }^{149}$.

En la diócesis de Cartagena-Murcia, dentro del clero capitular está documentada desde el siglo XIV la formación de pequeños linajes eclesiásticos muy relacionados con las principales familias de la oligarquía murciana, así como de otras partes de Castilla, que frecuentemente usan la fórmula de sucesión tío-sobrino. Así, muchos obispos llegados de fuera introdujeron en el cabildo una amplia parentela de sobrinos, mientras que las dignidades concedían también a sus sobrinos los puestos inferiores del cabildo, debiendo llamarse la atención sobre el hecho de que, a veces, esta relación tío-sobrino

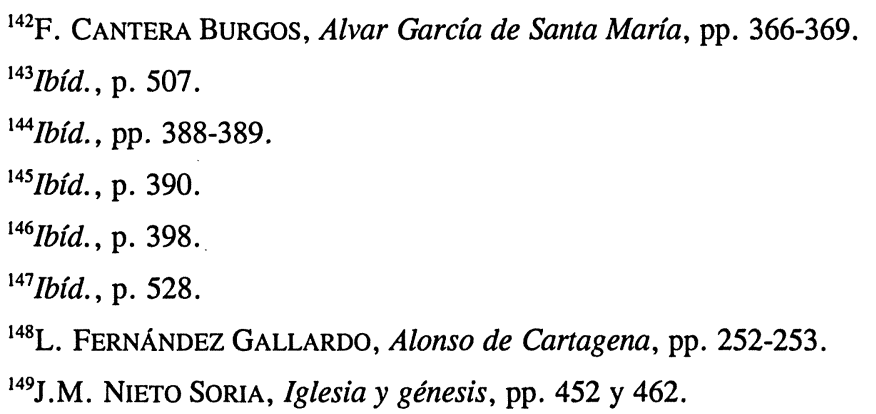


podía esconder una situación real de hijos ilegítimos, que frecuentemente conseguían la legitimación ${ }^{150}$.

Por lo general fue habitual en la Iglesia castellana que familiares y criados de los canónigos accediesen a los puestos más bajos de los cabildos, las raciones enteras y medias, o bien a alguno de los numerosos cargos cultuales o administrativos existentes en las catedrales, en calidad de servidores de la institución capitular. Por todo ello, es imprescindible establecer una adecuada relación entre los diversos niveles jerárquicos del cabildo y el status y procedencia social de sus integrantes, resultando también de gran interés averiguar la trayectoria prosopográfica y formación cultural de los diferentes miembros de la institución capitular.

Este interés manifiesto por ejercer un determinado grado de control sobre la institución capitular nos debe llevar a preguntarnos sobre el modo en que las oligarquías urbanas utilizaban el aparato de poder del cabildo, una vez integradas dentro del mismo, de cara a fortalecer su posición dentro del sistema político urbano. Así, desde esta perspectiva, cabría destacar tres funciones básicas en todo cabildo: una función económica, a través de la articulación de mecanismos de transferencia de rentas capitulares hacia grupos sociales privilegiados que obtenían el arrendamiento de las mismas, actuando a menudo como arrendatarios canónigos y laicos pertenecientes a determinados linajes; una función política en situaciones de conflictos y luchas urbanas entre diversas facciones nobiliarias, cuando el control sobre los diferentes resortes de poder se hacía especialmente necesario; y una función propagandística y legitimadora hacia ciertas familias, lo que se pone de manifiesto en aspectos como el mecenazgo nobiliario hacia la Iglesia y la fundación en los templos catedralicios por parte de determinados linajes de capillas familiares dotadas con múltiples elementos iconográficos y heráldicos.

\section{OTROS ECLESIÁSTICOS}

Aunque es sin duda dentro del Episcopado y en los cabildos catedralicios donde encontramos a un mayor número de eclesiásticos de extracción nobiliaria, también en otros ámbitos del clero habrá ocasionalmente representantes de la nobleza. Comenzaremos por el clero regular.

${ }^{150}$ I. GARCÍA DÍAZ; M. RodRÍGUEZ LLOPIS, Iglesia y sociedad feudal, pp. 62-63.

«Anuario de Estudios Medievales», 35/2 (2005), pp. 557-603.- ISSN 0066-5061. 
En líneas generales puede decirse que los eclesiásticos procedentes de los más destacados linajes de la nobleza no solían pertenecer a las órdenes mendicantes, y ello a pesar de algunas excepciones al respecto que su pueden citar. Tal sería el caso ya señalado del franciscano Juan Enríquez, hijo del almirante Alfonso Enríquez, confesor y testamentario de Enrique III, ministro provincial de los franciscanos de Castilla entre 1406 y 1409 y obispo de Lugo desde este último año hasta $1417^{151}$. Asimismo, cabe destacar al también franciscano Iñigo de Mendoza, hijo de Diego Hurtado de Mendoza y de Juana de Cartagena (nieta del obispo de Burgos Pablo de Santa María), miembro de la corte de Enrique IV y de los Reyes Católicos y limosnero de Isabel la Católica ${ }^{152}$. Otros ejemplos serían los obispos dominicos del siglo XV Fray Alonso de Burgos, vinculado a la familia conversa de los García de Santa María, y Fray Lope de Barrientos, procedente de la mediana nobleza. Por otro lado, Fray Martín de Santa María, perteneciente también al citado linaje judeconverso, fue desde 1430 prior de San Pablo de Burgos ${ }^{153}$, mientras que Fray Gonzalo Maluenda, sobrino del obispo don Pablo de Santa María, sería prior de San Juan de Ortega ${ }^{154}$.

Cabría citar asimismo a Isabel Arias, del linaje judeoconverso de los Arias Dávila de Segovia, que fue monja en el monasterio de Santa Clara de esta ciudad, llegando a provisora del mismo en $1487^{155}$. Por otro lado, dentro del linaje Manrique, mientras que los eclesiásticos del mismo se inclinaron muy poco hacia la profesión monástica, el elemento femenino, en cambio, sí optó algo más por dicha vocación monástica, aunque a veces por obligación paterna del linaje; en este sentido hay que señalar que fueron sobre todo las solteras y viudas las que ingresaron en monasterios, fundamentalmente de clarisas $^{156}$. Una hija del marqués de Santillana Iñigo López de Mendoza, doña Leonor, también fue monja clarisa ${ }^{157}$.

${ }^{151}$ J.M. NIETO SORIA, Iglesia y génesis, p. 433.

${ }^{152}$ Ibíd., p. 449.

${ }^{153}$ F. CANTERA BURgos, Alvar García de Santa María, p. 521.

${ }^{154}$ Ibíd., p. 394.

${ }^{155}$ David M. Gituitz, Los Arias Dávila de Segovia, p. 110.

${ }^{156}$ Rosa Ma MONTERo TEJADA, Nobleza y sociedad en Castilla. El linaje Manrique (siglos XIV-XVI), pp. 315-317. p. 388 .

${ }^{57}$ J. GARCía ORO, Francisco de Asís en la España medieval, Santiago de Compostela, 1988,

*Anuario de Estudios Medievales», 35/2 (2005), pp. 557-603.- ISSN 0066-5061. 
Para el caso de la archidiócesis de Sevilla, algunas investigaciones señalan que en el clero regular había menos presencia de miembros de origen noble que en el secular. Tenemos, por ejemplo, al dominico Fernando de Medina y al jerónimo Diego Martínez de Medina, fundador en 1414 y prior del convento de San Jerónimo de Buenavista, pertenecientes ambos a una destacada familia de la oligarquía local. Con todo, ciertos linajes sevillanos hicieron sentir su poder clientelar: Payo de Ribera, nieto del fundador de la cartuja de las Cuevas, fue procurador de la misma y prior de Miraflores, mientras que los Torres consiguieron el privilegio de enterrarse en la cartuja como reconocimiento de la comunidad al que fuera su prior, Fernando de Torres $^{158}$. En cuanto a las vocaciones monásticas femeninas entre la nobleza sevillana, podemos señalar, a modo de ejemplo, que en 1468 estaban en el monasterio de Santa Clara de la ciudad monjas como Mencia de Figueroa, que era además la abadesa, Leonor de Guzmán, Leonor Ponce y María de Medina ${ }^{159}$.

Pero, no obstante los casos recién señalados de miembros del clero regular procedentes de la nobleza en sus diferentes niveles, fue más frecuente entre los integrantes de las órdenes mendicantes y monásticas en general una extracción social mucho más baja.

Dentro del linaje Enríquez, al que perteneció el ya citado arzobispo de Sevilla García Enríquez Osorio (1442-1448), también se podría destacar a clérigos como el arcediano de Toro Rodrigo Enríquez, que fue reformador observante del convento de San Francisco de Palencia y protegido de Juan II, así como a Diego Enríquez del Castillo, cronista, consejero y capellán de Enrique IV ${ }^{160}$.

Precisamente varios importantes linajes castellanos contribuyeron decisivamente a impulsar la implantación en sus señoríos de la reforma observante franciscana, y esto se observa muy en especial en los Mendoza, mecenas y patronos de conventos de franciscanos y clarisas en toda Castilla, y defensores de la Observancia en el siglo XV, lo que también es aplicable, en menor medida, a otros linajes como los Enríquez, Manrique, Suárez de Figueroa, Pimentel y Fonseca ${ }^{161}$.

\footnotetext{
${ }^{158}$ Rafael SÁNCHEz SAUS, Caballería y linaje en la Sevilla medieval, Cádiz, 1989, p. 77.

${ }^{159}$ Archivo Catedralicio de Sevilla, sección IX, caj. 17, $n^{\circ} 4 / 4$.

${ }^{160} \mathrm{~J} . \mathrm{M}$. NIETO SORIA, Iglesia y génesis, p. 433.

${ }^{161}$ J. GARCíA ORO, Francisco de Asís, pp. 388-397.
} 
Las colegiatas seculares serán también otras instituciones eclesiásticas nutridas en ocasiones por clérigos de extracción nobiliaria, aunque generalmente en mucha menor medida que en los cabildos catedralicios. En Valladolid, por ejemplo, desde la segunda mitad del siglo XIV los eclesiásticos de la ciudad reforzarán sus vínculos con el patriciado urbano dominante, y muchos miembros, no todos, del cabildo de la colegiata de Santa María la Mayor y de algunos monasterios, sobre todo femeninos, procederán de la nobleza media-baja de la ciudad, sin que falten tampoco algunos representantes de grandes linajes señoriales como los Mendoza, Guzmán, Enríquez, Velasco o Acuña ${ }^{162}$. En 1441, por ejemplo, encontramos a Alfonso Velasco como abad de la colegiata de Santa María, además de ser consejero ocasional de Juan II, mientras que Fernando Velasco era capellán real en $1464^{163}$. Por otro lado, en la colegiata de Santa María de Husillos, en Palencia, encontramos en 1370 como canónigo a Juan Alfonso de Toledo, pariente del obispo palentino don Gutierre Gómez de Toledo ${ }^{164}$.

En muchas colegiatas, sin embargo, la extracción social de sus integrantes podía ser de lo más diversificada. Así sucedió, por ejemplo, en la colegiata de San Pedro de Soria, donde, si bien durante el siglo XV muchos puestos capitulares fueron controlados por pequeños linajes de la oligarquía local soriana como los Santa Cruz y Morales, o la familia judeoconversa de los Beltranes en el XVI, también habrá una importante presencia de canónigos procedentes de clases medias de burgueses y comerciantes ${ }^{165}$.

Diferentes a los cabildos catedralicios y colegiatas eran los cabildos que agrupaban al conjunto de clérigos beneficiados de un determinado lugar, donde a veces también podemos encontrar una cierta representación nobiliaria. A principios del siglo XVI, por ejemplo, en la villa de Ágreda, que, aunque perteneciente al reino de Castilla, dependía en lo eclesiástico del obispado de Tarazona, muchos beneficiados del cabildo de clérigos procedían del grupo de caballeros hidalgos del lugar, con los que compartían muchos intereses, siendo incluso frecuente la participación de clérigos en asuntos concejiles. Además, el sistema de provisión de beneficios eclesiásticos de la villa

\footnotetext{
${ }^{162}$ Adeline RuCQuOI, Valladolid en la Edad Media, Valladolid, 1987, II, pp. 313-332.

${ }^{163}$ J.M. NIETO SORIA, Iglesia y génesis, p. 462.

${ }^{164}$ F.J. FERNÁNDEZ CONDE, Gutierre de Toledo, p. 68.

${ }^{165} \mathrm{M}$. DiAGo HERNANDO, Notas sobre el origen social del clero capitular de El Burgo de Osma y Soria, pp. 51-60.
}

«Anuario de Estudios Medievales», 35/2 (2005), pp. 557-603.- ISSN 0066-5061. 
reservaba a los clérigos bautizados en sus parroquias los beneficios de las mismas, lo que motivaría conflictos entre familias que se disputaban la provisión de dichos beneficios ${ }^{166}$. Pero, no obstante el ejemplo señalado y otros que se podrían indicar, en las diócesis castellanas la presencia nobiliaria en este tipo de cabildos, cuando se daba, solía quedar circunscrita a clérigos de la baja nobleza, pues los procedentes de medianos y grandes linajes orientaban su atención fundamentalmente hacia los mucho más apetecibles beneficios de los cabildos catedralicios.

\section{CONCLUSIONES}

El proceso de incorporación de la nobleza castellana al alto clero constituye una dimensión esencial de análisis para un mejor conocimiento tanto de las estrategias sociales y de poder de los principales linajes nobiliarios como de la propia proyección sociopolítica de la Iglesia y su inserción en las estructuras de poder del reino, todo ello dentro del proceso de génesis del Estado Moderno en Castilla a fines de la Edad Media. Fue sobre todo dentro del Episcopado y cabildos catedralicios donde se produjo esta integración al clero de personajes procedentes del estamento nobiliario, que se fue intensificando a medida que avanzó la baja Edad Media, siendo este un proceso que se vio sin duda favorecido por el rápido ascenso social, sobre todo desde fines del XIV, de los principales linajes de la nobleza nueva, y la consolidación de las oligarquías urbanas, dado que todos ellos, muy integrados en las estructuras de poder civil del reino, también deseaban controlar en mayor o menor medida las estructuras de poder eclesiástico de mayor proyección política, que eran las mitras episcopales y cabildos catedralicios.

Los linajes de la alta o media-alta nobleza con una mayor presencia en el Episcopado castellano-leonés durante la baja Edad Media fueron los Fonseca, en el siglo XV y principios del XVI, con siete obispos; los Gómez de Toledo, sobre todo en el XIV, con seis obispos; los Manrique, con cinco obispos; los Albornoz, Guzmán, Luna y Carrillo, con cuatro cada uno; los Mendoza, desde fines del XIV, con tres; los Enríquez, en el XV, con tres; los Osorio, con tres; y los Álvarez de Toledo, Velasco, Acuña, Gudiel, Carvajal,

\footnotetext{
${ }^{166}$ M. Diago Hernando, El cabildo de clérigos de Ágreda a comienzos de la Edad Moderna, “Celtiberia", 91 (1997), pp. 46-48. 
Suárez de Figueroa y Zúñiga, cada uno de ellos con dos miembros del linaje dentro del Episcopado. En cambio linajes como los Pimentel, Silva, La Cerda o Ponce tuvieron una casi nula o muy escasa proyección episcopal. En cuanto a los linajes de judeoconversos, hay que destacar ante todo a los García de Santa María (o Cartagena) y linajes a ellos vinculados (como los Maluenda), donde hubo hasta siete obispos. Por otro lado, en linajes como los Gómez de Toledo, Fonseca o García de Santa María las sucesiones episcopales tíosobrino o incluso padre-hijo fueron algo habitual, siendo también frecuentes las relaciones de parentesco entre los prelados de linajes como los Luna, Albornoz, Manrique y Carrillo.

Respecto al número de diócesis donde aparecen representados en alguna ocasión cada uno de los mencionados linajes, cabe decir que los García de Santa María y linajes afines, así como los Manrique, estuvieron presentes hasta en doce diócesis cada uno; los Fonseca en once; los Mendoza en ocho diócesis; los Guzmán y Carvajal en seis; los Gómez de Toledo, Carrillo y Osorio en cinco; los Álvarez de Toledo, Luna, Enríquez y Acuña, en cuatro cada uno; los Gudiel, Albornoz, Velasco y Zúñiga en tres; y los Suárez de Figueroa en una. En las archidiócesis de Toledo, Sevilla y Santiago, que eran las de mayor prestigio, nivel económico y proyección política, los grandes linajes señoriales que más presencia tuvieron en el Episcopado de las mismas fueron los Mendoza, Manrique, Fonseca, Albornoz, Luna, Gómez y Álvarez de Toledo.

En el arzobispado de Toledo, además, dada su enorme relevancia política, encontraremos ocasionalmente al frente de la mitra a miembros de la Realeza castellana (el infante don Sancho de Castilla en el XIII) o aragonesa (don Sancho de Aragón en el XIII y el infante don Juan en el XIV), y también hay que destacar la presencia de hasta tres arzobispos del linaje de los Luna durante los siglos XIV y XV. Otro prelado vinculado a la Realeza, don Pedro de Castilla, nieto de Pedro I, ocuparía en el siglo XV las diócesis de Osma y Palencia, debiendo ser recordado aquí también el nombramiento del infante don Felipe, hijo de Fernando III, como procurador del arzobispado de Sevilla tras su restauración.

Asimismo, es interesante observar cómo algunos privados reales consiguieron colocar al frente ciertas mitras a sus familiares. Baste recordar en este sentido los casos don Juan de Cerezuela y Luna, hermanastro de don Álvaro de Luna, que fue obispo de Osma y arzobispo de Sevilla y Toledo, así como el del obispo de Palencia don Gutierre de la Cueva, hermano de Beltrán de la Cueva. 
Por otra parte, hay que llamar la atención sobre la proyección dentro del Episcopado que linajes gallegos como los Fonseca, Osorio y otros tendrán en diócesis del centro-norte peninsular como León, Salamanca, Oviedo, Astorga o Burgos. Los Fonseca incluso extenderán su influencia a los obispados de Sevilla, Cuenca o Ávila.

En definitiva, respecto al nivel de la extracción nobiliaria del Episcopado castellano, sin duda alguna las archidiócesis de Toledo, Sevilla y Santiago ocupan el puesto más alto. En el siglo XV, la alta nobleza también tuvo una muy significativa presencia en las diócesis de Sigüenza, Ávila, Mondoñedo, Osma, Palencia y Oviedo. En cambio en otros obispados, como por ejemplo Cádiz, Tuy o Ciudad Rodrigo, aunque esporádicamente pudo haber algún representante de grandes linajes, lo más habitual fueron los obispos de la baja nobleza e incluso de procedencia no nobiliaria. Además, en Cádiz, Ciudad Rodrigo y las diócesis extremeñas habrá una destacada presencia de obispos pertenecientes a las órdenes mendicantes. En las demás diócesis predominarán sobre todo los obispos procedentes de la mediana 0 baja nobleza urbana, con algún ocasional representante de la alta nobleza señorial, así como algún posible prelado de origen no noble.

Aparte de esta importantísima presencia de eclesiásticos de extracción nobiliaria en el Episcopado, durante la baja Edad Media también accedieron a los cabildos catedralicios clérigos pertenecientes a familias de los diversos niveles jerárquicos que componían en Castilla el estamento nobiliario, desde la alta nobleza hasta los simples caballeros e hidalgos, grupo éste muy numeroso, siendo también muy frecuente a partir del siglo XV el acaparamiento de cargos capitulares por miembros de familias conversas. Los eclesiásticos provenientes de destacados linajes la alta y mediana nobleza generalmente solían acceder a las dignidades, que eran los beneficios de mayor prestigio y cuantía económica dentro de los cabildos, y ello se observa, por ejemplo, en diócesis como Toledo, Santiago, Sevilla, León o Cuenca, mientras que en cabildos como los de Osma y Cádiz la presencia nobiliaria fue muy escasa. En este sentido hay que dejar bien claro que en casi todos los cabildos catedralicios hubo también clérigos que no procedían de la nobleza, a lo que hay que sumar asimismo la obtención, por otorgamiento pontificio, de prebendas capitulares por parte de eclesiásticos extranjeros, casi siempre absentistas.

Por último hay que señalar que, fuera del Episcopado y de los cabildos catedralicios, la proyección eclesiástica de la nobleza, sobre todo en sus más altos niveles, fue mucho menos importante, y quedó reflejada en la 
incorporación de algunos nobles al clero regular -básicamente órdenes mendicantes- o su presencia en algunas colegiatas o cabildos de clérigos de las diferentes ciudades del reino.

Podemos concluir, tal como se señaló al comienzo de este trabajo, que aún son necesarios estudios más exhaustivos sobre la integración nobiliaria en la alta jerarquía eclesiástica castellana, lo que permitiría ir extrayendo conclusiones más sólidas. Así, hay que analizar detalladamente los factores sociales, políticos y económicos que determinaban el grado de control ejercido por la nobleza local o señorial sobre los cabildos, comparando la mayor o menor presencia de cada linaje en concejo y cabildo, estudiando la evolución y cambios que se producían en todo el proceso de luchas urbanas por el control de los resortes de poder civil y eclesiástico, todo ello enmarcado en un amplio contexto de mutuas relaciones de poder entre Iglesia, nobleza y Monarquía. Finalmente, también habría que estudiar las razones que en algunas diócesis permitieron el acceso de la nobleza local a la mitra episcopal de la propia ciudad, mientras que en otros lugares ello no fue posible, para lo cual sería necesario analizar pormenorizadamente y de forma individualizada el mayor o menor control que cada cabildo tuvo sobre las elecciones episcopales y el alcance de la participación regia, pontificia y nobiliaria que se produjo en las mismas.

«Anuario de Estudios Medievales», 35/2 (2005), pp. 557-603.- ISSN 0066-5061. 


\section{APÉNDICE}

Principales linajes con representación en el Episcopado castellano bajomedieval

ACUÑA

-Alonso Vázquez de Acuña: obispo de Mondoñedo (1455-1457) y Jaén (1457-1474).

-Luis de Acuña y Osorio: obispo de Segovia (1449-1456) y Burgos (1456-1495).

ALBORNOZ

-Fernando Álvarez de Albornoz: arzobispo de Sevilla (1371-1377).

-Gil Álvarez de Albornoz: arzobispo de Toledo (1338-1350). Cardenal.

-Pedro Álvarez de Albornoz: arzobispo de Sevilla (1378-1390).

-Pedro Gómez Barroso de Albornoz: obispo de Sigüenza (1348-1358), Coimbra (1358-1364), Lisboa (1364-1369), y arzobispo de Sevilla (1369-1371). Cardenal.

ÁlVAREZ DE TOLEDO

-García Álvarez de Toledo: obispo de Astorga (1463-1488).

- Gutierre Álvarez de Toledo: obispo de Palencia (1423-1439), arzobispo de Sevilla (1439-1442) y Toledo (1442-1445).

\section{CARRILLO}

-Alonso Carrillo de Acuña: obispo de Sigüenza (1435-1446) y arzobispo de Toledo (1446-1482).

-Alonso Carrillo de Albornoz: obispo de Osma (1408-1422) y Sigüenza (14221434). Cardenal.

-Álvaro Gómez Carrillo: obispo de Palencia (1297-1305).

-Alonso Carrillo: obispo de Ávila (el. 1496).

CARVAJAL

-Bernardino López de Carvajal: obispo de Astorga (1488-1489), Badajoz (14891493) y Sigüenza (1495-1511).

-Juan de Carvajal: obispo de Coria (1443-1446), Plasencia (1446-1470) y electo de Zamora (1467). Cardenal.

DÁVILA (en sus diferentes ramas)

-Domingo Blasco: obispo de Ávila (1213-1239).

-Sancho Blázquez: obispo de Ávila (1312-1355).

- Juan Arias Dávila: obispo de Segovia (1461-1497).

-Rodrigo Dávila: obispo de Plasencia (1470-1492). 


\section{ENRÍQUEZ}

-García Enríquez Osorio: obispo de Oviedo (1441-1442) y arzobispo de Sevilla (1442-1448).

-Juan Enríquez: obispo de Lugo (1409-1417).

-Pedro Enríquez de Castro: obispo de Mondoñedo (1427-1445).

\section{FONSECA}

-Alonso de Fonseca el Viejo: obispo de Ávila (1445-1454), arzobispo de Sevilla (1 ${ }^{\text {a }}$ vez, 1454-1460), Santiago (1460-1464) y nuevamente de Sevilla (1464-1473).

-Alonso de Fonseca: arzobispo de Santiago ( $\left.1^{\mathrm{a}} \mathrm{vez}, 1460\right)$, Sevilla (1460-1464) y nuevamente de Santiago (1464-1506).

-Alonso de Fonseca: arzobispo de Santiago (1506-1523) y Toledo (1523-1534).

-Alonso de Fonseca: obispo de Ávila (1469-1485), Cuenca (1485-1493) y Osma (1493-1505).

-Diego de Fonseca: obispo de Orense (1470-1486).

-Juan Rodríguez de Fonseca: obispo de Badajoz (1495-1499) y Córdoba (el. 1499).

-Pedro de Fonseca: obispo de Astorga (1413-1419) y Sigüenza (1419-1422). Cardenal.

\section{GARCÍA DE SANTAMARÍA (CARTAGENA) Y LINAJES VINCULADOS}

-Alonso de Cartagena: obispo de Burgos (1435-1456).

-Gonzalo de Cartagena: obispo de Astorga (1419-1423), Plasencia (1423-1446) y Sigüenza (1446-1448).

-Pablo de Santa María: obispo de Cartagena (1403-1415) y Burgos (1415-1435).

-Alonso de Burgos: obispo de Córdoba (1477-1482), Cuenca (1482-1485) y Palencia (1485-1499).

-Alonso Rodríguez Maluenda: obispo electo de Salamanca (1447).

-Juan Ortega Maluenda: obispo de Coria (el. 1503?)

-Juan Díaz de Coca: obispo de Oviedo (1467-1470) y Calahorra (1470-1477).

GÓMEZ DE TOLEDO

-Gutierre Gómez de Toledo: arzobispo de Toledo (1311-1319).

-Gutierre Gómez de Toledo: obispo de Palencia (1357-1381). Cardenal.

-Gutierre Gómez de Toledo: obispo de Oviedo (1377-1389).

-Gutierre de Toledo: obispo de Plasencia (1496-1506).

-Suero Gómez de Toledo: arzobispo de Santiago (1362-1366).

- Vasco Fernández de Toledo: obispo de Palencia (1343-1353) y arzobispo de Toledo (1353-1362).

GUDIEL

-Gonzalo García Gudiel: obispo de Cuenca (1280-1288). 
-Gonzalo Pérez Gudiel: obispo de Cuenca (1273-1275), Burgos (1275-1280) y Toledo (1280-1298).

GUZMÁN

-Diego Ramírez de Guzmán: obispo de León (1344-1354).

-Diego Ramírez de Guzmán: obispo de Oviedo (1412-1441).

-Fadrique de Guzmán: obispo de Mondoñedo (1457-1492).

-Juan Ramírez de Guzmán: obispo de Tuy (1390-1394), Calahorra (1394-1403) y Ávila (1403-1424).

LUNA

-Jimeno de Luna: arzobispo de Toledo (1328-1338).

-Juan de Cerezuela y Luna: obispo de Osma (1422-1433) y arzobispo de Sevilla (1433-1434) y Toledo (1434-1442).

-Pedro de Luna: arzobispo de Toledo (1403-1414).

-Rodrigo de Luna: arzobispo de Santiago (1449-1460).

MANRIQUE

-Íñigo Manrique de Lara: obispo de Oviedo (1444-1457), Coria (1457-1475), Jaén (1475-1483) y arzobispo de Sevilla (1483-1485).

-Íñigo Manrique de Lara: obispo de León (1484-1485) y Córdoba (1485-1496).

-Juan García Manrique: obispo de Orense (1371-1375), Sigüenza (1376-1381), Burgos (1381-1382) y arzobispo de Santiago (1382-1399).

-Gómez Manrique: obispo de Tuy (1348-1351) y arzobispo de Santiago (1351-1362) y Toledo (1362-1375).

-Guillermo García Manrique: obispo de Oviedo (1389-1397).

\section{MENDOZA}

-Diego Hurtado de Mendoza: obispo de Palencia (1470-1485) y arzobispo de Sevilla (1485-1502).

-Lope de Mendoza: obispo de Mondoñedo (1393-1399), arzobispo de Santiago (1400-1445) y administrador apostólico de Osma (1404-1408).

-Pedro González de Mendoza: obispo de Calahorra (1453-1467), Sigüenza (14671495), arzobispo de Sevilla (1474-1482) y Toledo (1482-1495), y administrador apostólico de Osma (1482). Cardenal.

OSORIO

-Álvaro Pérez Osorio: obispo de Lugo (1434-1440) y Astorga (1440-1463).

-Gonzalo Osorio y Villalobos: obispo de León (1301-1313) y Burgos (1313-1327).

-Luis Osorio: obispo de Jaén (1483-1496).

«Anuario de Estudios Medievales», 35/2 (2005), pp. 557-603.- ISSN 0066-5061. 
SUÁREZ DE FIGUEROA

-Gómez Suárez de Figueroa: obispo de Badajoz (1479-1486).

-Lorenzo Suárez de Figueroa: obispo de Badajoz (1444-1461).

VELASCO

-Luis de Velasco: obispo de León (1478-1484) y Córdoba (1484).

-Rodrigo Velasco: obispo de Palencia (1417-1423).

ZÚÑIGA

-Diego López de Zúñiga: obispo de Calahorra (1408-1443).

-Gonzalo de Zúñiga: obispo de Plasencia (1415-1422) y Jaén (1422-1457). 